\title{
Sustainable Animal Feed Protein through the Cultivation of YARROWIA Lipolytica on Agro-Industrial Wastes and by-Products
}

\author{
Sotiris I. Patsios ${ }^{1, *(\mathbb{D}, \text { Anna Dedousi }}{ }^{2}$, Evangelia N. Sossidou ${ }^{2}$ and Antonios Zdragas ${ }^{2}$ \\ 1 Laboratory of Natural Resources and Renewable Energies, Chemical Process and Energy Resources Institute, \\ Centre for Research and Technology Hellas, Thermi, GR570 01 Thessaloniki, Greece \\ 2 Veterinary Research Institute, Hellenic Agricultural Organization-Demeter, Thermi, GR570 01 Thessaloniki, \\ Greece; dedousi@vri.gr (A.D.); sossidou@vri.gr (E.N.S.); zdragas@vri.gr (A.Z.) \\ * Correspondence: patsios@cperi.certh.gr; Tel.: +30-2310-498-183
}

Received: 27 December 2019; Accepted: 7 February 2020; Published: 14 February 2020

\begin{abstract}
Proteins are essential constituents of animal feeds, which comprise mainly vegetable protein (e.g., soybean meal), which is produced and transported globally. The decoupling of protein-production and livestock-growth areas results in protein deficiencies in certain parts of the world, and in significant environmental stress. Alternative, more sustainable protein feeds are necessary to meet the increasing needs, and to decrease the environmental footprint of animal products. Yeast Single Cell Proteins (SCP), produced locally using various agro-industrial by-product streams, have significant potential as alternative animal feed protein. Particularly, Yarrowia lipolytica, an oleaginous, non-pathogenic microorganism has been characterized as a "workhorse" in biotechnological studies, drawing the attention of many researchers. The present review summarizes available resources on critical issues concerning the applicability and commercialization of Yarrowia lipolytica as an environment-friendly protein source for animal feed. It discusses the sustainability of the yeast SCP production process, it presents the recent advances concerning Yarrowia lipolytica cultivation on low-cost agro-industrial by-products, and it stresses the effects on the health and welfare of productive animals due to the inclusion of Yarrowia lipolytica in their diet. The data presented in this study should facilitate relative research advancement and the commercialization of Yarrowia lipolytica's use as an alternative protein source/supplement for animal feeds.
\end{abstract}

Keywords: Single Cell Protein; Yarrowia lipolytica; sustainability; productive animal diet; fodder supplement; agro-industrial wastes; by-products

\section{Introduction}

Animal product consumption is expected to continue growing in the following years; the World Health Organization (WHO) estimations on per capita consumption of livestock products by 2030 is $134.8 \mathrm{~kg}$ per year, increased approx. 18\% compared to 1999 [1]. Given also the increase in the world population by approx. 2.5 billion people between 1999 and 2030 [2], the world feed supply for livestock husbandry should increase by approx. $66 \%$, given that feed efficiency/digestibility remains the same [3].

Protein is a limiting ingredient in the production of animal feed, and vegetable protein is currently used as the main protein source; $97 \%$ of the 334.56 million tons [4] of soybean meal produced globally is used as animal feed [3]. The decoupling of protein-meals-production and livestock-growth areas, results in protein deficiencies in animal feeds in certain parts of the world. For example, Europe, where the agro-climatic conditions are not ideal for the cultivation of soybean crop (e.g., lower yields 
and longer growing time), has to import approx. two-thirds of the total protein feed demand [3]. However, this practice raises significant sustainability issues; it has been calculated that the production of " $1 \mathrm{~kg}$ of soybean meal produced in Argentina and delivered to Rotterdam Harbor" results in the emission of $721 \mathrm{~g} \mathrm{CO}_{2}$ eq. for global warming potential, $3.1 \mathrm{~g} \mathrm{SO}_{2}$ eq. for acidification potential, whereas the average farming area per $1 \mathrm{~kg}$ of soybean meal is approx. $3.6 \mathrm{~m}^{2}$ per year [5]. In China, the self-sufficiency of soybean is projected to decrease to approx. 16\%, till 2020 [3].

Rapeseed meal is another by-product from the oil industry with high content of vegetable protein. Rapeseed has the advantage that it is produced locally to protein deficient areas (e.g., Europe) and can substitute soybean meal in animal feeds. However, concerning sustainability, rapeseed meal can result to equal or even higher environmental impacts. Lehuger et al. [6] compared the environmental impacts of two feeds for dairy cows, which contained either soybean meal imported from Brazil, or locally produced rapeseed meal. The Life Cycle Assessment (LCA) showed that soybean meal is more environmentally efficient since-being a legume crop-it requires less nitrogen fertilizer, reduced crop management, and produces lower direct emissions. The equivalent $\mathrm{CO}_{2}$ emissions for $1 \mathrm{~kg}$ of either soybean or rapeseed meal rations were 391 and $471 \mathrm{gr}$, respectively, whereas the land use for soybean ration was approx. $36 \%$ lower.

The use of alternative, more sustainable protein feeds/supplements seems to be necessary to replace, at least partly, the current supply chains, to meet the increasing needs, and ultimately to decrease the environmental footprint of animal products [3]. Another reason for this transition arises from the fact that traditional animal protein feeds compete with human food resources for the use of agricultural land. Therefore, novel feed protein sources, such as insect meal, micro- and macro-algae, protein-rich food industry by-products and Single Cell Protein (SCP), characterized by the fact that they can be produced locally and that they have low agricultural land use requirements [7], have significant potential as alternative animal feed proteins [3].

SCP was first mentioned by workers at MIT back in 1968 [8]; the term refers to production of protein-rich food or feed from single cell microorganisms like yeast, bacteria or fungi, although some of the microorganisms (fungi) may in true be multicellular [9]. Use of SCP for livestock feed dates back to the start of $20^{\text {th }}$ century in Germany; during World War I Saccharomyces cerevisiae (brewer's yeast), which is the second largest by-product from brewing, replaced up to $60 \%$ of the previously imported feed protein [10]. British Petroleum (BP) developed a process for the cultivation of Yarrowia lipolytica on waxy n-paraffins, a low-cost by-product of petroleum industry, for animal feed [11]. A pilot plant of 100,000 tons per year capacity has been built; however, safety concerns given the substrate origin, and its high price after the 1973 oil-crisis resulted in the cease of BP's interest on SCP [9]. The Imperial Chemical Industries (ICI) commercialized an SCP production method, using methanol as substrate and Pseudomonas methylotrophus bacteria, to produce Pruteen $®$, a $72 \%$ protein-content product for animal feed. However, the process could not operate economically at the present methanol price, which represents approx. $50 \%$ of the total cost of the product. It is estimated that methanol-based SCP in USA is two- to five-fold the cost of fishmeal [12].

The above-mentioned paradigms demonstrate two significant bottlenecks related to commercialization of SCP processes: (a) the cost of substrate, and (b) safety concerns/public acceptance. Yeasts were the first microorganisms that were used as animal feed supplements [10]. Their adoption is greatly facilitated by their high acceptability; Saccharomyces cerevisiae has been used for centuries in various traditional food fermentation processes (e.g., bread, wine and beer production). Yarrowia lipolytica strains have been found in the native biocommunity of various food products such as meat, fish, dairy products (e.g., cheeses, yogurts, etc.) soy sauce and other high-lipids foods [11,13]. Yeast have various advantages including larger size, thus easier harvesting, lower nucleic acid content, thus lower post-treatment cost, high lysine content, and the ability to grow at an acidic $\mathrm{pH}$, thus lower risk for spoilage [12]. Moreover, yeasts may grow on various substrates, including agro-industrial wastes co- and by-products (AWCB), thus lowering the main production cost $[9,12,14,15]$. 
Yarrowia lipolytica is a non-conventional ascomycetous yeast that has been extensively used for various biotechnological applications and has been studied and engineered in numerous studies as a model oleaginous yeast $[13,16,17]$, being able to produce and store intracellular lipids in contents higher than $20 \% w / w$ of its biomass $[13,18]$. Its genome has been sequenced, and there are many bioinformatics tools, which allow setting-up different metabolic engineering strategies for this yeast. Therefore, Yarrowia lipolytica has been characterized as a "workhorse" for biotechnological applications [19], e.g., mainly for production of single-cell oil and other valuable products using various industrial wastes as substrate [20]. Moreover, Yarrowia lipolytica is classified as Generally Regarded As Safe (GRAS) for citric acid production by the American Food and Drug Administration (FDA), and it is assumed to be safe for feed and food applications, as non-pathogenic [11,21].

Yarrowia lipolytica has attracted the attention of many researchers and numerous studies due to its favorable inherent characteristics for various biotechnological applications. More specifically, it can grow under high salt, low temperature and low $\mathrm{pH}$ conditions [13]; the latter is highly important, since it minimizes the risk for culture contamination and may eliminate the need for high energy-consuming sterilization processes and expensive sterilization equipment. Yarrowia lipolytica can use as substrate a variety of both hydrophilic (e.g., glucose, fructose, alcohols, organic acids and glycerol) and hydrophobic substrates (e.g., fatty acids, lipids, n-acetates etc.) $[13,18,22]$, and at the same time it accumulates lipids in its cell at concentrations over $40 \% w / w$ of its dry cell weight [16]. It produces various useful secondary metabolites such as citric acids, pyruvates, polyols, emulsifiers etc. [13,18,23]; and may excrete various lipolytic and proteolytic enzymes $[13,17,18]$. Finally, Yarrowia lipolytica has high protein content and contains rather high concentrations of essential amino acids like lysine [24,25].

Therefore, Yarrowia lipolytica seems a strong candidate for production of SCP, mainly for animal feed, either as a stand-alone process or as a by-product of the biotechnological production of biolipids, citric acid, lipases, and other high-value bio-based chemicals. Yarrowia lipolytica optimum growing conditions are ambient temperatures (e.g., $28-30{ }^{\circ} \mathrm{C}$ ) and mild acidic $\mathrm{pH}$ values (around 5.5), which both favor process economics. Moreover, low doubling times, around 2.0 to $4.0 \mathrm{~h}$, have been reported in the literature [26,27]. Critical issues associated with the large-scale commercialization of the use of Yarrowia lipolytica as SCP in animal feed comprise the use of low-cost substrates, mainly originating as AWCB; the applicability and benefits of its use as SCP in animal feed; and the sustainability of its production process compared to current vegetable proteins.

A recent search on Scopus ${ }^{\circledR}$ database has revealed a significant number of studies, more than one hundred per year in the last three years (2016-2018) with the term "Yarrowia lipolytica" in their title. The number of studies has steadily increased over the last ten years (Figure 1), and there have already been 90 studies published in the current year (2019). In the last five years (2015-2019), many review articles summarizing the main outcomes of this great number of studies have been released. Most reviews focus on the recent advancements concerning the cellular and metabolic engineering of the microorganism either to produce non-native high-value products $[17,20,28-32]$ or to increase/improve the productivity and yield of conventional products (e.g., citric acid, bio-lipids etc.) [13,19,33-38]. Comparatively, there are fewer reviews describing biotechnological applications of Yarrowia lipolytica growing on alternative low-cost substrates that decrease its cultivation cost; the most recent reviews are provided by Carsaba et al. [13] and Spangnuolo et al. [22] that summarize relevant studies published till 2017. On the other hand, there is no review that focuses on the application of Yarrowia lipolytica as SCP in productive animal feed, although there are many relative papers. Likewise, there are no studies that assess the environmental sustainability of the cultivation of Yarrowia lipolytica, and only few studies that assess sustainability of yeast SCP production for animal feed. 


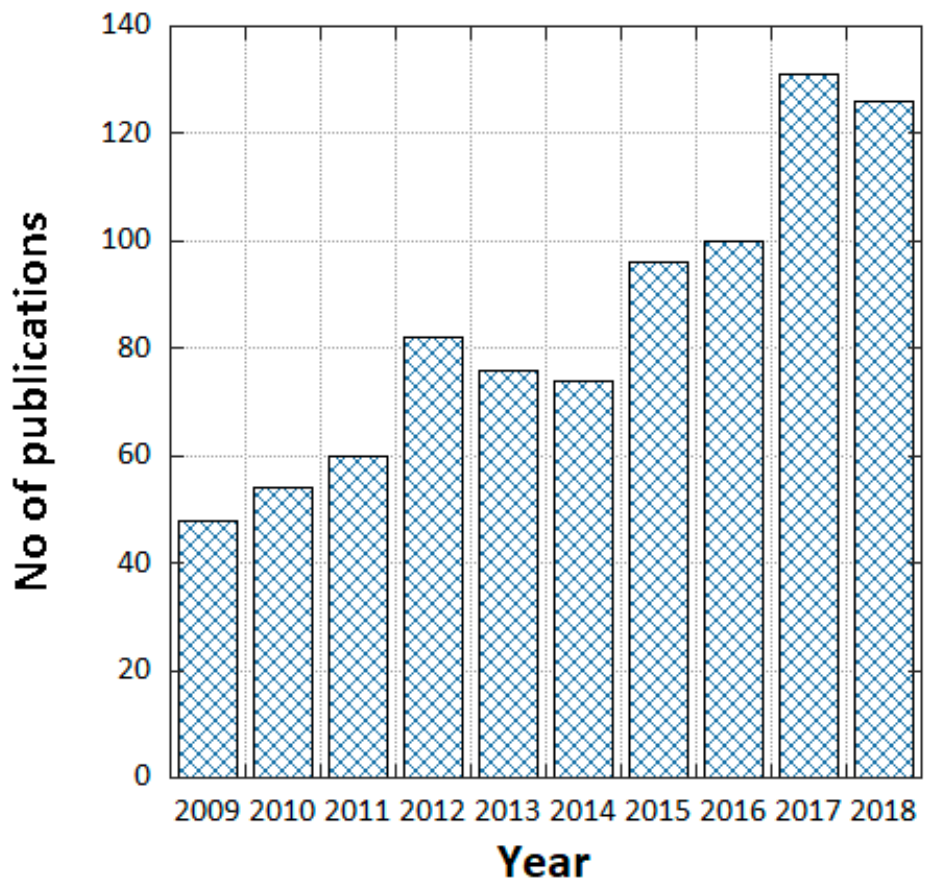

Figure 1. Number of studies with the term "Yarrowia lipolytica" in their titles for the years 2009-2018, according to Scopus ${ }^{\circledR}$ database.

The objective of the current review is to summarize the available resources on critical issues concerning the applicability and commercialization of Yarrowia lipolytica as an environment-friendly protein source/supplement for animal feed. This article first discusses the sustainability of SCP production, with an emphasis on yeast-derived SCP for animal feed, compared to the base-case scenario of vegetable protein. Next, it provides a recent update on the published data during the last two years (2018-2019) concerning the growth of Yarrowia lipolytica on low-cost AWCB, which favors the economic and environmental sustainability of the process. Finally, it provides an exclusive review on the use of the microorganism in productive animal diet, stressing its effects on animals' health and welfare. This interdisciplinary approach aims to provide a spherical resource that would serve as a base for future developments towards the commercialization of the cultivation of Yarrowia lipolytica on AWCB substrates for SCP uses.

\section{Sustainability Assessment of SCP Production}

To evaluate the environmental impact of a system, process or a product, there are specific life-cycle approaches and methodologies that can be used. LCA is a "cradle-to-grave" analysis that assesses the environmental stresses imposed throughout all stages of the life-cycle of a product or process, employing public available inventories and case-specific data concerning the materials and energy used. There are widely accepted standard procedures for performing an LCA study (e.g., ISO 14040 and 14044), which focus on the methodology for conducting the LCA study, and-despite the criticism concerning specific issues of the LCA methodology (e.g., quality of inventory, assumption impacts etc.) - life-cycle tools are very useful for the comparison of the environmental sustainability of competitive products/processes.

According to two recent studies, that used LCA methodology to compare the environmental impacts of soybean meal against various alternative protein meals for salmon [39] and broiler feed [7], yeast-based SCP is considered to be more environment-friendly compared to imported vegetable protein (e.g., soybean meal). Couture et al. [39] assessed the environmental impact of salmon feeds formulated and used in a salmon farm located in Norway. The main protein sources considered were soybean meal, produced and imported from America, against bacteria protein meal (BPM), produced and imported 
from the USA, and yeast protein meal (YPM), produced locally in Norway. Wheat hydrolysate is used as substrate for bioethanol production, and YPC is considered as a by-product of bioethanol production. The yeast cells are harvested, condensed and dried for YPC production. Moreover, two salmon feed formulations, FA1 (on an equal protein base) and FA2 (on an equal protein and lipid base) were also assessed after the substitution of soybean meal with BPM and YPM. The different protein meals and the two feed formulations were assessed based on the following impact indicators: Climate Change ( $\mathrm{kg} \mathrm{CO} 2$ eq.), Acidification ( $\mathrm{kg} \mathrm{SO}_{2}$ eq.), Freshwater Consumption $\left(\mathrm{m}^{3}\right)$, Freshwater Eutrophication ( $\mathrm{kg}$ P eq.), Land Occupation ( $\mathrm{m}^{2}$ annually), Marine Eutrophication ( $\mathrm{kg} \mathrm{N}$ eq.) and Primary Production Requirement ( $\mathrm{kg} \mathrm{C})$.

YPM impact on all categories compared to soy protein concentrate was drastically lower (Figure 2). Most impacts were mainly associated with soy farming in soybean meal. Although, YPM production is based on crop-based substrates, the allocation of farming impacts with high-value biofuels, renders these impacts quite lower. YPM has considerably lower climate change impacts than soybean meal, mainly due to soy farming that accounts for $64 \%$ of the climate change impact. Concerning the main categories of atmospheric pollution, YPM has one order of magnitude lower impact (e.g., $0.206 \mathrm{~kg}$ $\mathrm{CO}_{2}$ eq. and $0.001 \mathrm{~kg} \mathrm{SO}_{2}$ eq. for climate change and acidification, respectively), compared to soymeal and BPM which have similar climate change impact, i.e., 8.55 and $8.26 \mathrm{~kg} \mathrm{CO}_{2}$ eq., respectively. Another area for which both BPM and YPM have a significantly different impact over soybean is land occupation, which was calculated as being equal to 0.148 and $0.243 \mathrm{~m}^{2}$ annually for BPM and YPM, respectively; in contrast soymealrequired approx. $3.724 \mathrm{~m}^{2}$ annually for its production. On the other hand, the differences in freshwater eutrophication impact was comparable, ranging from $0.00008 \mathrm{~kg} \mathrm{P}$ eq. for YPM to $0.00043 \mathrm{~kg}$ P eq. for soybean meal.

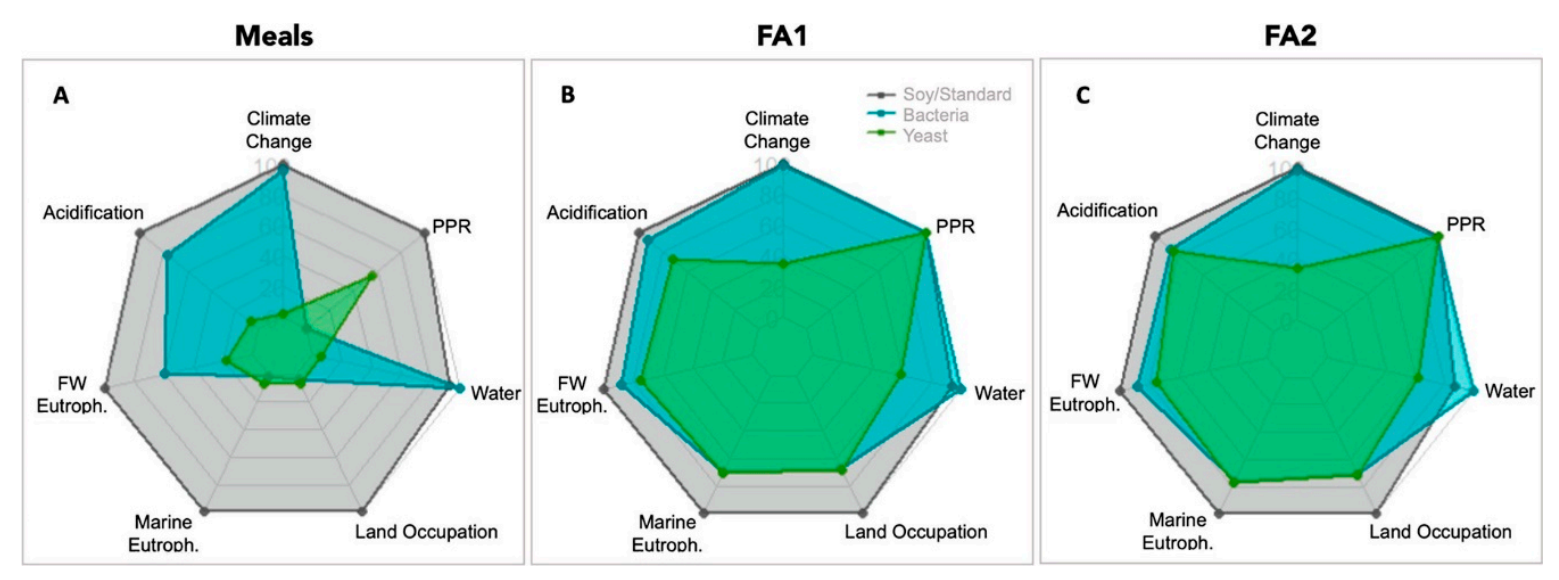

Figure 2. Radar charts comparing the three (soy-based (gray), bacteria-based (blue), yeast-based (green)) meals (A) and salmon feeds (B, C) based on seven impact indicators. Axes for each of the impact indicators: (from the top counterclockwise) climate change, acidification, freshwater eutrophication, marine eutrophication, land occupation, water consumption, primary production requirement (PPR). Results are scaled to the highest value for each indicator. Reprinted (adapted) with permission from Environ. Sci. Technol. 2019, 53, 4, 1967-1975 [39]. Copyright 2019 American Chemical Society.

The same trend is also encountered for FA1 and FA2 feed formulations; however environmental benefits of YPM are significantly reduced since protein meals comprise approx. only $20-25 \%$ of the total salmon feed. Nonetheless, YPM-based FA1 has the lowest levels of impact concerning all environmental indicators, apart from the primary production requirements index which is similar for all feeds, ranging between $22.54 \mathrm{~kg} C$ for BPM and $22.62 \mathrm{~kg} \mathrm{C}$ for soybean meal in the FA1 case, and between $22.41 \mathrm{~kg} \mathrm{C}$ for BPM and $22.62 \mathrm{~kg} \mathrm{C}$ for soybean meal in the FA2 case. It should be noted that the climate change indicator of YPM-based feed was approx. one-third (e.g., 1.05 and $1.04 \mathrm{~kg} \mathrm{CO}_{2}$ eq. for FA1 and FA2, respectively) compared to conventional soybean-based feed $\left(3.04 \mathrm{~kg} \mathrm{CO}_{2}\right.$ eq. for both FA1 and FA2). Concerning the acidification potential, the difference of the impact between the 
YPM-based and the soybean-based meal is significantly lower, approx. $28.4 \%$ lower for FA1 and $15.4 \%$ for FA2.

Given that each LCA model is based on a number of assumptions, Couture et al. [39] performed sensitivity analyses to assess the effect of the production location and the allocation method that was employed (e.g., economically-based vs. mass-based). While the results had small variations, the relative results were the same. The authors also noted that there is lack of data concerning the effect of the novel feeds on salmon growth efficiency; therefore, more research (e.g., feeding trials) is necessary for a more detailed assessment of the sustainability of the alternative feeds. Moreover, they proposed developments in the production of the SCP that would further decrease the environmental footprint of the novel feeds. Bacterial SCP could use biomethane instead of methane for their growth, whereas yeast SCP growth should be pursued using agro-industrial byproducts instead of food-related substrates.

Tallentire et al. [7] examined the environmental impacts of incorporating new protein sources into broiler feeds, compared to the current (base-case) scenario of soybean meal. Diets were formulated based on the specific nutritional profile of each protein-rich ingredient. Soybean meal was imported in Europe, whereas yeast protein concentrate (YPC) was produced as a by-product from bioethanol production with wheat hydrolysate as substrate. The main environmental indicators used were greenhouse gas (GHG) emissions, agricultural land use (ALU), and the produced nutrients (N and $\mathrm{P}$ ). An amount of $1 \mathrm{~kg}$ of YPC was estimated to result in $1.08 \mathrm{CO}_{2}$ eqv. $\mathrm{kg}$, whereas the environmental impact per $\mathrm{kg}$ of soybean meal was $3.05 \mathrm{CO}_{2}$ eqv. $\mathrm{kg}$. Moreover, the ALU for YPC was also significantly reduced; 1.26 and $3.11 \mathrm{~m}^{2} / \mathrm{kg}$ for YPC and soymeal, respectively. Therefore, it is obvious that YPC produced locally as a by-product from other agro-industrial processes is more sustainable than soybeans cultivated in vast monocultures in South America over deforested Amazon land [40]. On the other hand, YPC has higher total N and P content, e.g., $0.108 \mathrm{~kg} \mathrm{~N} / \mathrm{kg}$ and $0.013 \mathrm{~kg} \mathrm{P} / \mathrm{kg}$, compared to soymeal $(0.075 \mathrm{~kg} \mathrm{~N} / \mathrm{kg}$ and $0.006 \mathrm{~kg} \mathrm{P} / \mathrm{kg})$. This difference may be due to the high RNA content of yeast cells compared to soymeal and resulted in higher total $\mathrm{N}$ and $\mathrm{P}$ excretion compared to conventional diet. These results probably denote that the inclusion of the novel ingredients (e.g., YPC) at a maximum inclusion rate may decrease the efficiency of protein conversion, and therefore more focus should be placed on the inclusion rate of the novel protein source to obtain comparable/equal efficiencies.

Another point worth mentioning is that Tallentire et al. [7] considered that the inclusion of the novel ingredients did not affect the bird growth rate or its health conditions. However, results from the inclusion of Yarrowia lipolytica in other productive bird diets (e.g., turkey hens) have shown that the incorporation of dry yeast in a dose of 3\% to $6 \%$, stimulates the body's immune defense mechanisms [41]. Therefore, it seems that further research is necessary on the effects of the novel ingredients (e.g., SCP) on animals' health, feed efficiency and overall productivity. Data concerning the optimum inclusion dose of SCP in animals' diet would decrease the uncertainty of the various sustainability studies and would facilitate the commercialization of $\mathrm{SCP}$, as well as of other alternative protein ingredients, in animal feed.

\section{Yarrowia Lipolytica Cultivation on Low-Cost AWCBs}

The use of low-cost AWCB as substrate for cultivation of Yarrowia lipolytica yeast was first documented by Scioli et al. [42], who used olive oil mill wastewater as substrate for the growth of strain ATCC 20,255. The experiments in a $3.5 \mathrm{~L}$ fermenter showed that the yeast could grow on olive oil mill wastewater, reducing the organic fraction by approx. $80 \%$ within $24 \mathrm{~h}$, producing yeast biomass (approx. $22.5 \mathrm{~g} / \mathrm{L}$ ) and lipases enzymes. This study demonstrated the versatile characteristics of Yarrowia lipolytica and its ability to grow on low-cost agro-industrial wastes.

Given that economic viability of biotechnological processes is significantly affected by the substrate cost, many studies demonstrate the growth of Yarrowia lipolytica on various low- or no-cost substrates, either through the exploitation of the native ability of the yeast to use different carbon sources [19], or after the biotechnological engineering of specific strains to expand the range of fermentable substrates [35]. Numerous reviews [13,22,43-46], report the use of various AWCBs as substrate 
including: olive oil mill wastewater, palm oil mill effluent, soybean oil refinery waste, fishmeal waste, tallow, crude glycerol, lignocellulosic hydrolysates, molasses, waste oils, etc. Till 2014, most studies on the use of AWCB-based substrates for Yarrowia lipolytica were focused on hydrophobic (e.g., oily) waste streams or upgrade of solid wastes (e.g., fishmeal, barley bran) [45,46]. However, the exponential growth of biodiesel production, resulted in the increase of its by-product and waste streams. Therefore, many studies demonstrate the use of crude glycerol (whose production rate has greatly surpassed its demand) and other by-products of biodiesel production (e.g., fatty acids, degumming wastes, etc.) for the growth of Yarrowia lipolytica yeast [13,43]. It is noted that the only reported case of commercial production of Yarrowia lipolytica SCP is by the Skotan Company SA in Poland that produces SCP for animal feed based on glycerol and degumming residues as a substrate.

Over the last couple of years, fifteen studies have reported the growth of Yarrowia lipolytica yeast on AWCB substrates (Table 1). Most of these studies (e.g., seven) use hydrophobic/oily waste streams [47-54], six refer to crude glycerol [48,51,53,55-57], four to agro-industrial and food waste hydrolysates [58-61], and three to various agro-industrial waste streams including: mango wastes [62], sugarcane molasses [63], and papaya [54]. Various wild and engineered yeast strains were tested for the production of many different products including: SCP [47,50,53,56], biolipids [47-52,59,61], organic acids (mainly citric and succinic) [47,55,56,58,60], and enzymes (mainly lipases) [48,53,54,62]. Although most of the studies are focused on other high-value products apart from SCP, the yeast biomass, after recovery of the main product of interest (e.g., biolipids), would still contain high protein content, rendering it useful as supplement in animal feed.

Louhasakul et al. [48], studied the production of biolipids from Yarrowia lipolytica yeast, and optimized biolipids accumulation, thus achieving a maximum biolipids content of $52.7 \% \pm 2.8 \%$ $w / w$. At the same time, the biomass contained approx. $20 \% w / w$ protein. After biolipids extraction, which account for approx. half of the initial biomass weight, the de-fatted biomass would contain approx. $40 \% \mathrm{w} / \mathrm{w}$ of protein, which is very close to the content of soybean meal. In another study, Juszczyk et al. [50] cultivated various strains of Yarrowia lipolytica on pure and raw glycerol, and other linseed oil wastes. Lab-scale experiments on flasks resulted in biomass with approx. 19.4-48.2\% $w / w$ protein and $7.3-30.5 \% w / w$ biolipids. The results were similar concerning protein content, with strains growing on either pure or raw glycerol. This is very important, since raw glycerol is a low-cost by-product of the biodiesel industry, whereas pure glycerol is used for pharmaceutical, food and cosmetic purposes. The yeast protein was further analyzed and was found to contain all the Essential Amino Acids (EAA) in significant quantities. The sum of EEA in the various samples ranged between 28.5 and $48.9 \mathrm{~g} / 100 \mathrm{~g}$ of total protein, which is comparable to the standard amino acid content of whole egg, which has a sum of EEA equal to $49 \mathrm{~g} / 100 \mathrm{~g}$. Moreover, the lysine content was $62.9 \%$ to $100 \%$ of the lysine content of the whole egg protein. However, apart from protein, Yarrowia lipolytica biomass contained significant quantities of biolipids which comprise high concentration of mono-unsaturated fatty acids, mainly oleic, palmitic, and linoleic acids. The sum of these three mono-unsaturated fatty acids varied from $52.6 \%$ to $81.8 \%$ of total biolipids, whereas the total unsaturated fatty acids were between $78.2 \%$ and $88.5 \%$ of total biolipids. 
Table 1. Overview of studies on Yarrowia lipolytica growth on low-cost AWCBs.

\begin{tabular}{|c|c|c|c|c|c|c|}
\hline Yeast Strain & AWCB & $\begin{array}{c}\text { Targeted } \\
\text { Product/Application }\end{array}$ & $\begin{array}{l}\text { Protein Content } \\
(\% w / w \text { DW) }\end{array}$ & $\begin{array}{c}\text { Biolipid Content } \\
(\% w / w \text { DW) }\end{array}$ & Culture Mode/Size & Reference \\
\hline ACA-DC 5029 & $\begin{array}{l}\text { Crude glycerol; Olive oil mill } \\
\text { wastewater }\end{array}$ & $\begin{array}{l}\text { SCP; Biolipids; Citric acid; } \\
\text { Polyols }\end{array}$ & - & 10.6-20.0 & Flask/50 mL & Sarris et al. [47] \\
\hline $\begin{array}{c}\text { A101 (AJD } \\
\text { pADUTGut1/2) }\end{array}$ & Crude glycerol & Citric acid & - & - & Flask/50 mL; Batch/2 L & Rzechonek et al. [55] \\
\hline PSA02004 & $\begin{array}{c}\text { Sugarcane bagasse } \\
\text { hydrolysate }\end{array}$ & Succinic acid & - & - & Batch/1 L & Ong et al. [58] \\
\hline TISTR 5151 & $\begin{array}{l}\text { Palm oil mill effluent; Crude } \\
\text { glycerol }\end{array}$ & Biolipids & $20.2 \pm 0.5$ & $52.7 \pm 2.8$ & Flask/90 mL & Louhasakul et al. [48] \\
\hline W29 (ATCC 20460) & Waste cooking oils & Biolipids; Lipases & - & $9.8-47.8$ & Batch/2 L & Lopes et al. [49] \\
\hline $\begin{array}{c}\text { Po1f } \\
\left(\text { pex10- } \mathrm{mfe}-\mathrm{leu}^{+}\right)\end{array}$ & Apple pomace hydrolysate & Biolipds & - & $\max .64 .2$ & Fed-batch/- & Liu et al. [59] \\
\hline PGC202 & $\begin{array}{l}\text { Mixed food waste; Fruit and } \\
\text { vegetable waste; Agricultural } \\
\text { waste hydrolysates }\end{array}$ & Succinic acid & - & - & $\begin{array}{c}\text { Flask/50 mL; Batch/1 L; } \\
\text { Fed-batch/1 L }\end{array}$ & Li et al. [60] \\
\hline $\begin{array}{l}\text { S5, S6, S9, S10, S11, } \\
\text { S12, S17, A311, 1.31, } \\
\text { and K1 }\end{array}$ & Lineseed oil wastes & SCP; Biolipids & $19.4-48.2$ & $7.3-30.5$ & Flasks/75 mL; Batch/1.5 L & Juszczyk et al. [50] \\
\hline $\begin{array}{l}\text { A101, AJD, AJD } \\
\text { pAD-DGA1 }\end{array}$ & Crude glycerol & Biolipids & - & $\max .38 .0 \pm 0.8$ & Flasks/30 mL; Batch/2 L & Dobrowolski et al. [51] \\
\hline CBS6303 & $\begin{array}{l}\text { Vegetable oil refinery } \\
\text { wastewater }\end{array}$ & Biolipids & - & $\max .60 .1$ & Flasks/50 mL; Batch/2.5 L & Darvishi et al. [52] \\
\hline IMUFRJ 50682 & $\begin{array}{l}\text { Mango wastes (peel, } \\
\text { tegument and kernel) }\end{array}$ & Lipases & - & - & Flasks/300 mL; Batch/3 L & Pereira et al. [62] \\
\hline YLY & $\begin{array}{l}\text { Sugarcane molasses; Waste } \\
\text { cooking oil; Crude glycerol }\end{array}$ & SCP, Lipases & $45.0-54.0$ & - & Batch/4 L & Yan et al. [53] \\
\hline A-10 & Crude glycerol, Fatty acids & SCP, Keto-acids & $32.8-50.5$ & 13.4 & Batch/2 L & Krzysztof et al. [56] \\
\hline DSM 8218 & Food waste leachates & Biolipids & - & $48.9 \pm 1.5$ & Flasks/100 ml & Johnravindar et al. [61] \\
\hline Polg & Papaya seed oil & Recombinant antibody & - & - & Flasks/- & Han et al. [54] \\
\hline
\end{tabular}


Yan et al. [53] engineered a Yarrowia lipolytica strain to enhance lipases and SCP production. The engineered strains were grown on various AWCB substrates including, e.g., crude glycerol, sugarcane molasses, and waste cooking oil. The protein content of the biomass ranged between $45.0 \%$ $w / w$ and $54 \% w / w$ and contained all the EAA. Except for cystine, the amino acid profile of Yarrowia lipolytica covered between $93.9 \%$ (for phenylalanine) and $111.4 \%$ (for threonine) of the FAO reference standard for EEA [63]. The Yarrowia lipolytica amino acid profile was only deficient to cystine, providing $47.9 \%$ of cystine according to FAO standard. Therefore, Yarrowia lipolytica SCP was considered suitable for use as animal feed protein supplement. Krzysztof et al. [56] cultivated Yarrowia lipolytica under various carbon substrates including AWCB like glycerol and fatty acids from biodiesel production. The cultures were grown in a continuous stirred bioreactor, of $2 \mathrm{~L}$ operating volume, under aerobic conditions and acidic $\mathrm{pH}(3.5-4.5)$. The biomass grown on fatty acids substrate contained $32.8 \% w / w$ protein, whereas the protein content of biomass grown on glycerol contained approx. $50.5 \% w / w$ and $13.4 \% w / w$ of protein and biolipids, respectively. The majority of the biolipids were unsaturated fatty acids $(77.7 \%)$, rendering Yarrowia lipolytica biomass useful as protein supplement in animal feeds.

Another low-cost substrate that has been used for the growth of Yarrowia lipolytica is the hydrolysate of AWCBs or food wastes. Ong et al. [58] used sugarcane bagasse, which was alkaline pre-treated, and employed enzymatic hydrolysis (Celluclast $1.5 \mathrm{~L} ; 40 \mathrm{FPU} / \mathrm{g}$ sugarcane bagasse) to release fermentable sugars. The PSA02004 strain was cultivated in a continuously stirred bioreactor of $1 \mathrm{~L}$ working volume, under aerobic conditions and neutral $\mathrm{pH}(\mathrm{pH}=6.0)$. During the batch fermentation, the glucose in the sugarcane hydrolysate (initial concentration approx. $48 \mathrm{~g} / \mathrm{L}$ ) was completely consumed within $80 \mathrm{~h}$, whereas the xylose (initial concentration approx. $20 \mathrm{~g} / \mathrm{L}$ ) was consumed by approx. $50 \%$ within $100 \mathrm{~h}$. The maximum dry cell mass (DCM) concentration of Yarrowia lipolytica was approx. $10 \mathrm{~g} / \mathrm{L}$, which was achieved after $80 \mathrm{~h}$ of fermentation; afterwards, probably due to the concurrent exhaust of glucose, the DCM concentration decreased to approx. $7.5 \mathrm{~g} / \mathrm{L}$ at the end of the experiment. Liu et al. [59] used apple pomace, which was pre-treated with the alkaline-hydrogen peroxide method to remove lignin, followed by pectinase to remove pectin that cannot be fermented by Yarrowia lipolytica. Then, the pre-treated pomace was enzymatically hydrolyzed with commercial cellulases (Cellic CTec2 and Cellic Htec2, Novozymes, Switzerland). The hydrolysate sugar content comprised glucose (61.05\%), arabinose $(17.1 \%)$, xylose $(12.06 \%)$ and galactose $(9.87 \%)$, and was used as substrate in a fed-batch bioreactor operated under aerobic conditions $\left(\mathrm{pO}_{2}\right.$ levels $\left.>20 \%\right)$ and $\mathrm{pH}=5.5$ with initial sugar concentration of $80 \mathrm{~g} / \mathrm{L}$. The maximum DCM concentration with apple pomace hydrolysate was approx. $40.2 \mathrm{~g} / \mathrm{L}$, after $144 \mathrm{~h}$ of fermentation, whereas the biolipids content reached $64.2 \%$, on the sixth day of the test. Surprisingly, the fermentation yield of the mixed sugars of apple pomace hydrolysate was higher than a reference fermentation with glucose substrate, under the same conditions.

Li et al. [60] used mixed food wastes (MFW), fruit and vegetable wastes (FVW) and agricultural wastes (AW) which were hydrolyzed for the release of fermentable sugars. MFW and FVW were enzymatically hydrolyzed with commercial enzymes, whereas AW were first pre-treated with alkaline hydrolysis (for lignin removal), followed by enzymatic hydrolysis. Each hydrolysate contained different concentrations of glycose; $60.0 \mathrm{~g} / \mathrm{L}, 56.7 \mathrm{~g} / \mathrm{L}$, and $44.8 \mathrm{~g} / \mathrm{L}$ for MFW, FVW and AW hydrolysates, respectively. During, batch fermentations in a bioreactor ( $1 \mathrm{~L}$ volume) at $28{ }^{\circ} \mathrm{C}$ and with no $\mathrm{pH}$ control, the glucose was depleted within 66h, 55h and 80h for MFW, FVW and AW hydrolysates, respectively. The $\mathrm{pH}$ in all fermentations was acidic (between 4.0 and 5.0), and the DCM concentration at the end of the batch fermentations was approx. $20.0 \mathrm{~g} / \mathrm{L}, 19.7 \mathrm{~g} / \mathrm{L}$, and $24.2 \mathrm{~g} / \mathrm{L}$ for MFW, FVW and AW hydrolysates, respectively. Fed-batch fermentations were also employed in an in-situ fibrous bed bioreactor with MFW hydrolysate, supplemented with $3 \% w / v$ tryptone, and no $\mathrm{pH}$ control. Fresh substrate was added after glucose was nearly depleted $(<10 \mathrm{~g} / \mathrm{L})$, and the $\mathrm{pH}$ dropped from the initial value $\mathrm{pH}=4.9$ to $\mathrm{pH}=2.9$ after $180 \mathrm{~h}$ of fermentation. The DCM concentration steadily increased to 45.5 $\mathrm{g} / \mathrm{L}$ by the end of the fed-batch fermentation test. Johnravindar et al. [61] cultivated Yarrowia lipolytica on anaerobic raw leachates/hydrolysates of MFW. The leachates $(\mathrm{pH}=4.5)$ were sterilized and the $\mathrm{pH}$ was adjusted to 6.0 using $\mathrm{NaOH}$. The main carbon substrates were volatile fatty acids (VFA), mainly 
acetic and lactic acid that varied between 28.4 and $80.4 \mathrm{~g} / \mathrm{L}$, and carbohydrates, whose concentration varied between 70.0 and $111.0 \mathrm{~g} / \mathrm{L}$. DSM 8218 strain was grown on diluted leachates (1:2-1:3), in flasks for a period of $144 \mathrm{~h}$. The maximum CDM concentration reached was $20.9 \mathrm{~g} / \mathrm{L}$ and the biolipids content ranged from approx. $26.2 \%$ to $48.9 \%$. Although the experiments were performed in small scale $(10 \mathrm{~mL}$ flasks), it was shown that the Yarrowia lipolytica strain can grow using mixed-carbon sources (mainly sugars and organic acids) of food and agricultural waste hydrolysates.

Other researchers used hydrophobic AWCB streams to cultivate Yarrowia lipolytica yeast. Sarris et al. [47] cultivated ACA-DC 5029 strain in various mixtures of crude glycerol with olive oil mill wastewater. Although crude glycerol (with an initial concentration of $70 \mathrm{~g} / \mathrm{L}$ ) was the main carbon source, olive mill wastewater was used instead of water for dilution of the crude glycerol. Interestingly, the existence of polyphenols did not seem to negatively affect the growth of Yarrowia lipolytica, even when the initial polyphenols concentration reached $3.5 \mathrm{~g} / \mathrm{L}$. On the contrary, the addition of the oily AWCB seemed to promote the production of citric acid and biolipids, probably through triggering specific lipogenic metabolic pathways. Lopes et al. [49] studied the use of waste cooking oil as the sole carbon source for the growth of Yarrowia lipolytica. Waste cooking oil was selected as a low-cost food waste that is currently under-utilized and/or wasted. Experiments were performed in a $2 \mathrm{~L}$ bioreactor, operated in batch mode, with $10 \mathrm{~g} / \mathrm{L}$ of initial concentration of waste cooking oil. Tween 80, a commercial surfactant, was also added to promote dispersion of waste cooking oil in the bioreactor. The oxygen transfer coefficient was found to have a positive effect on cellular growth. Since Yarrowia lipolytica is an aerobic yeast, an approx. ten-fold increase in the oxygen transfer coefficient resulted in the increase in the DCM concentration from $2.8 \pm 0.3$ to $9.8 \pm 1.2 \mathrm{~g} / \mathrm{L}$, whereas the biolipids content ranged between $9.8 \%$ and $47.8 \% w / w$. Darvishi et al. [52] used vegetable oil wastewater, containing approx. 3-4 g/L of oil and grease, as carbon source for the growth of Yarrowia lipolytica. Initially, the substrate composition was optimized in flask experiments, followed by cultivation in a $2.5 \mathrm{~L}$ bioreactor, under batch-mode operation with an initial vegetable oil wastewater content of $7.5 \% \mathrm{v} / \mathrm{v}$. The maximum DCM concentration was approx. $18.0 \mathrm{~g} / \mathrm{L}$ after $14 \mathrm{~h}$ of growth, whereas after $20 \mathrm{~h}$ of cultivation the vegetable oil substrate was totally consumed. Pereira et al. [62], given that $35-60 \%$ of the mango fruit is discarded as waste during its processing, used various mango waste streams for the growth of Yarrowia lipolytica. Mango peel, tegument and kernel-alone or in various mixtures-were used as substrates in batch experiments for the growth of IMUFRJ 50,682 wild strain, aiming to lipases production. The tegument showed promising results for Yarrowia lipolytica growth, and the cultivation conditions were optimized following a fractional factorial design. The best conditions (e.g., approx. $1 \mathrm{~g} / \mathrm{L}$ of mango tegument, $\mathrm{pH}=5.0$, approx. $28.0^{\circ} \mathrm{C}$, and $2 \mathrm{~g} / \mathrm{L}$ yeast extract) were tested in a batch operated bioreactor for approx. $38 \mathrm{~h}$.

\section{Yarrowia Lipolytica as Supplement in Productive Animal Feed}

Currently, the most commonly used yeast in animal feed is Saccharomyces cerevisiae [24]. Comparison of the nutrition values of Yarrowia lipolytica, Saccharomyces cerevisiae, soybean meal and rapeseed meal shows that there are no great differences on the main nutrition parameters (Table 2). Soybean meal presents the highest protein content with a mean value equal to $51.8 \% w / w \mathrm{DM}$, followed by Yarrowia lipolytica with $43.5 \%$ w/w DM. Dry matter and ash content are comparable for the four protein sources, with mean values ranging from $87.9 \% w / w$ (soybean meal) to $96.5 \% w / w$ (Yarrowia lipolytica) and $7.1 \%$ w/w DM (soybean meal) to $8.0 \%$ w/w DM (Yarrowia lipolytica, Saccharomyces cerevisiae), respectively. Concerning crude fat, soybean and rapeseed meal have higher fat contents (i.e., $2.0 \%$ and $2.7 \% w / w$ DM, respectively) than SCP. However, Yarrowia lipolytica, under specific operating conditions, can maximize its biolipids content at concentrations higher than $20 \% w / w \mathrm{DM}$; in fact biolipid contents as high as $60.1 \% w / w$ DM have been reported [52]. 
Table 2. Nutrients concentration of Yarrowia lipolytica, Saccharomyces cerevisiae, soybean meal and rapeseed meal $[24,64,65]$.

\begin{tabular}{lcccccccccccc}
\hline \multirow{2}{*}{ Parameter } & \multicolumn{3}{c}{ Y. Lipolytica } & \multicolumn{3}{c}{ S. Cerevisiae } & \multicolumn{3}{c}{ Soybean Meal } & \multicolumn{3}{c}{ Rapeseed Meal } \\
\cline { 2 - 12 } & Min & Max & Mean & Min & Max & Mean & Min & Max & Mean & Min & Max & Mean \\
\hline $\begin{array}{l}\text { Crude protein } \\
(\% \text { w } w \text { DM })\end{array}$ & 39.0 & 48.0 & 43.5 & 31.1 & 49.0 & 40.1 & 45.2 & 56.1 & 51.8 & 34.8 & 41.9 & 38.3 \\
$\begin{array}{l}\text { Dry matter } \\
(\% \text { w } w \text { ) }\end{array}$ & 95.0 & 98.0 & 96.5 & 89.8 & 96.2 & 93.0 & 85.0 & 92.1 & 87.9 & 85.3 & 92.3 & 88.8 \\
$\begin{array}{l}\text { Crude ash } \\
(\% \text { w } w \text { DM })\end{array}$ & 7.8 & 8.3 & 8.0 & 7.4 & 8.6 & 8.0 & 6.1 & 9.4 & 7.1 & 6.6 & 9.1 & 7.8 \\
$\begin{array}{l}\text { Crude fat } \\
(\% \text { w } w \text { DM })\end{array}$ & 0.5 & 2.5 & 1.5 & 0.4 & 0.6 & 0.5 & 0.6 & 4.4 & 2.0 & 0.6 & 5.4 & 2.7 \\
\hline
\end{tabular}

Comparative studies concerning the chemical composition and nutritive value between Saccharomyces cerevisiae and Yarrowia lipolytica yeasts have shown that although the raw protein content is similar in both species, Yarrowia lipolytica contains much more extract of ether (Table 2) and polyunsaturated fatty acids [24,25], (Table 3) and more essential amino acids such as lysine [24,25]. However, differences are also observed in the levels of mineral and vitamin content [24]. The interesting chemical composition of Yarrowia lipolytica, namely its high protein content (43.5\%), essential amino acids, crude fat (2.5\%), B complex vitamins and inorganic salts, can offer an alternative to its use in animal nutrition instead of yeast Saccharomyces cerevisiae [24,25].

Table 3. Yarrowia lipolytica's fatty acid profile compared to Saccharomyces cerevisiae (\% w/w, DM basis) ${ }^{1}$ [25].

\begin{tabular}{|c|c|c|}
\hline Item & Yarrowia Lipolytica & Saccharomyces Cerevisiae \\
\hline C18:1 & $55.69 \pm 0.13$ & $29.41 \pm 0.10$ \\
\hline C18:2 & $26.66 \pm 0.09$ & $8.89 \pm 0.13$ \\
\hline C18:3n-3 & $5.85 \pm 0.17$ & $0.38 \pm 0.06$ \\
\hline C16:0 & $5.71 \pm 0.06$ & $17.78 \pm 0.12$ \\
\hline C16:1 & $1.99 \pm 0.18$ & $31.98 \pm 0.09$ \\
\hline C18:0 & $1.45 \pm 0.14$ & $4.60 \pm 0.11$ \\
\hline SFAs ${ }^{1}$ & $8.32 \pm 0.17$ & $28.12 \pm 0.02$ \\
\hline MUFAs ${ }^{1}$ & $57.68 \pm 0.26$ & $62.49 \pm 0.23$ \\
\hline PUFAs $^{1}$ & $34.11 \pm 0.17$ & $9.71 \pm 0.13$ \\
\hline
\end{tabular}

${ }^{1}$ Data are mean and standard deviation of two observations per treatment per each yeast; SFAs, MUFAs, PUFAs, saturated, monounsaturated, polyunsaturated fatty acids, respectively.

The American Food and Drug Administration, examining the safety issues of yeast Yarrowia lipolytica, has characterized both the yeast and its various fermentation products as being generally safe to use (GRAS) [11]. In 2010 and 2016, the European Feed Manufacturers' Federation authorized the Yarrowia lipolytica yeast (catalog number 00575-EN) and selenium enriched Yarrowia lipolytica yeast (catalog number 06113-EN) to be sold in the European Union as a feedstuff. As characteristically mentioned for Yarrowia lipolytica: "This strain converts the glycerol fraction formed during biofuel production into a yeast biomass with beneficial nutrient properties, such as a high content of easily digestible protein and vitamins. Thanks to these properties, biomass can be used as a high-value feedstuff". The list of feed materials in accordance with European Commission Regulation (EU) 2017/1017 also includes Yarrowia lipolytica yeast from biodiesel process by-products. More specifically, the list considers Yarrowia lipolytica yeasts and their parts, grown in vegetable oils, degumming by-product streams, and glycerol fractions, formed during the production of biofuels [66]. Since 2009, the Polish Skotan Company SA introduced a new process for the SCP production of Yarrowia lipolytica, grown on a mixture of crude glycerol and degumming residues from biodiesel production. The annual production of SCP reaches 1200 tons with a protein content between $41 \%$ and $45 \%$ [67]. Recently, the European Food and Safety Authority (EFSA) declared the Yarrowia lipolytica yeast biomass as a 
Novel Food (NF) safe for use pursuant to Regulation (EU) 2015/2283 on dietary supplements intended for the general population over 3 years of age [21]. According to the above report, the maximum proposed daily use levels are $3 \mathrm{~g} /$ day for children aged from 3 to less than 10 years of age and $6 \mathrm{~g} /$ day thereafter. Moreover, EFSA Panel concludes that considering the composition of NF and the proposed use levels, the consumption of the NF is not nutritionally disadvantageous.

The use of Yarrowia lipolytica yeast in animal feed is rather new and has not been studied extensively. There are research evidence indicating that the protein of Yarrowia lipolytica growing on industrial glycerol can perfectly complement the protein of wheat, barley and triticale in animal diets, upgrading their protein nutritional value [68]. Previous research using this strain of yeast as a dietary supplement has been carried out on turkeys [41,69,70], piglets [24,71,72], calves [73] and fish such as Atlantic salmon [74,75], Pacific red snapper [76] and Cynoglossus semilaevis [53].

\subsection{Effects of Yarrowia Lipolytica as Feed for Turkeys}

The addition of dry Yarrowia lipolytica to the diets of turkey hens aged 1-16 weeks old, at the doses of $3 \%$ and $6 \%$, replacing an equal amount of soybean meal, reduced the percentage of abdominal fat in their carcasses without having any adverse effect on birds' health, as demonstrated by their ordinary increase in body weight and with the hematological indices of blood which remained within the reference range [70]. However, better results on birds' body weight at week 16 of the experiment were achieved using Yarrowia lipolytica yeast at a dose of 3\%. Moreover, the application of the yeast in a dose of 3\% increased the number of red cells, while a dose of $6 \%$ increased hemoglobin levels in the blood of the birds, denoting the positive impact of Yarrowia lipolytica on the erythropoietic process. These findings were attributed to the high content of Yarrowia lipolytica on iron and copper, which are components of red blood cells [70].

In a later study, Merska et al. [69] revealed that the administration of dried Yarrowia lipolytica yeast in turkey hens' diet at an inclusion level of $3 \%$ or $6 \%$ did not cause oxidation reactions in birds' bodies. According to their findings, this yeast activates the enzymatic response of birds' antioxidant system. In particular, they observed that it increases catalase activity (CAT) and decreases plasma concentrations of lipid peroxidation products such as hydroperoxide ( $\mathrm{LOOH})$ and malondialdehyde (MDA), mostly by raising the iron blood levels.

Similar studies have shown that the incorporation of dry Yarrowia lipolytica yeast in turkey hens' diet at $3 \%$, but mostly at $6 \%$, activates body's immune defense mechanisms [41]. This activation was demonstrated by an elevation in plasma levels of lysozyme concentration, of the percentage of phagocytic cells (\% PC), and of the phagocytic index (PI). Moreover, a reduction in the monocyte ratio $(\mathrm{H} / \mathrm{L})$ in turkey hens' blood, which is considered a stress indicator in birds, was also observed. An additional positive effect of using Yarrowia lipolytica in the nutrition of turkey hens, at the above-mentioned percentages, was the decrease in blood levels of cholesterol, triglycerides and LDL-cholesterol fraction, which are consider indexes of lipid peroxidation, and the elevation in the percentage of HDL-cholesterol fraction. Finally, the fluctuation of biochemical parameters within the reference range, confirmed the findings of Merska et al. [70] on the non-adverse effect of the dietary use of Yarrowia lipolytica on birds' health.

\subsection{Effects of Yarrowia Lipolytica as Feed for Dairy Calves}

Stefanska et al. [73] investigated the nutritional impact of Yarrowia lipolytica culture supplementation to the colostrum or the milk replacer on the ruminal fermentation, on certain blood biochemical parameters and on the performance of Holstein-Friesian calves. Yarrowia lipolytica was added into colostrum or calf milk replacer at a dose of $30 \mathrm{~g} /$ day, $\left(15 \mathrm{~g} /\right.$ feeding; $\left.10^{8} \mathrm{CFU} / \mathrm{g}\right)$ during the first 56 days of the calves' lives. The addition to the liquid feed of calves resulted in increased consumption of the starter feed, increased growth rates and increased body capacity (as evaluated by measuring body length, hip width and heart girth). Furthermore, calves that received Yarrowia lipolytica yeast culture in their diet showed improved metabolic status and better early function of the rumen. These findings 
were indicated by higher counts of the protozoa Holotricha and Entodiniomorphida, as well as of the total number of bacteria in reticuloruminal fluid, and by the increased serum levels of $\beta$-hydroxybutyrate (BHBA), non-esterified fatty acids (NEFA), blood urea nitrogen (BUN) and the total calcium in the animal's blood, compared to controls at both days 14 and 42 of the experiment.

The exact mechanism that has led to better rumen function in calves fed Yarrowia lipolytica remains unclear. Stefanska et al. [73] did not exclude that Yarrowia lipolytica culture may act by altering the digestion at the intestines, which could indirectly have an effect on rumen development. In their study, at the calves fed Yarrowia lipolytica, blood BHBA concentration was increased. Previous reports demonstrate that serum BHBA is a good indicator for ruminal wall development and metabolic activity [77]. Yarrowia lipolytica cultures could indirectly improve reticulorumen development, thereby leading to increased starter feed intake and, thus, to alterations in the ruminal microbiota population [73].

Despite that the total number of ruminal bacteria and protozoa of genus Holotricha and Entodiniomorphida was increased in calves fed with Yarrowia lipolytica yeast, some fermentation markers such as $\mathrm{pH}$ of reticuloruminal fluid, ammonia nitrogen and volatile fatty acids concentrations remained unaffected [73]. This finding possibly indicates that Yarrowia lipolytica treated calves have improved capacity of absorbing fermentation products in blood circulation. This hypothesis can be supported by the increased serum concentrations of BHBA, NEFA and BUN recorded on days 14 and 42 of experimental period, in Yarrowia lipolytica treated group. Plasma BHBA concentration in calves is considered as an indicator of ruminal fermentation and function of ruminal epithelial cells, which convert the highest amount of butyrate produced in the rumen into BHBA [78]. Serum NEFA concentration is an indicator of lipid mobilization from the adipose tissue and, consequently, of negative energy in dairy cows and possibly in calves. However, the higher NEFA values observed in calves could be also due to the consumption of a high fat content diet [79]. According to Stefanska et al. [73], greater fat intake in animals that received Yarrowia lipolytica cultures may also be attributed to the consumption of a diet complemented with fat-rich yeasts. The increased BUN levels in calves may reflect an increased dietary nitrogen intake and possibly a more effective function of forestomaches [80]. Overall, the higher observed levels of blood biochemical parameters noticed in calves supplemented with Yarrowia lipolytica yeast culture could indicate an increased metabolic status due to the increased feed intake. Finally, serum total calcium concentration in calves receiving Yarrowia lipolytica in their feed was higher in comparison with the control group, which was translated to some extent into improved body development, as it was indicated by the increased length, hip width and heart girth measurements [73].

\subsection{Effects of Yarrowia Lipolytica as Feed for Piglets}

Comparative studies performed by Czech et al. [24] revealed that the chemical composition and nutritional value of Saccharomyces cerevisiae - that is currently considered the most commonly used fodder yeast - is not superior compared to Yarrowia lipolytica. In addition, the content of crude fat in Yarrowia lipolytica is three times the content in S. cerevisiae whereas Yarrowia lipolytica has about 30\% higher lysine and tryptophan content as well as 50\% higher alanine content than S. cerevisiae yeast (Table 4). Furthermore, Yarrowia lipolytica has a higher content of Ca, Mn, Mg, B2 and B12 and a lower content of P, vitamin E and B1 compared to S. cerevisiae (Table 4). 
Table 4. Amino acids ( $\mathrm{g} \mathrm{kg}^{-1} \mathrm{DM}$ basis), minerals ( $\mathrm{g} \mathrm{kg}^{-1} \mathrm{DM}$ basis), and vitamins ( $\mathrm{mg} \mathrm{kg}^{-1} \mathrm{DM}$ basis) of Yarrowia lipolytica compared to Saccharomyces cerevisiae [24].

\begin{tabular}{|c|c|c|c|c|c|c|}
\hline \multirow{2}{*}{ Parameter } & \multicolumn{3}{|c|}{ Yarrowia Lipolytica } & \multicolumn{3}{|c|}{ Saccharomyces Cerevisiae } \\
\hline & Min. & Max. & MEAN & Min. & Max. & Mean \\
\hline \multicolumn{7}{|c|}{ Amino Acids } \\
\hline Aspartic acid & 25.39 & 46.21 & 35.80 & 30.02 & 38.88 & 34.45 \\
\hline Threonine & 10.22 & 29.98 & 20.10 & 15.85 & 18.77 & 17.31 \\
\hline Serine & 16.68 & 19.68 & 18.18 & 18.44 & 21.26 & 19.85 \\
\hline Glutamic acid & 49.81 & 71.56 & $60.68^{a}$ & 45.87 & 53.35 & $49.61^{\mathrm{b}}$ \\
\hline Proline & 14.70 & 19.62 & $17.16^{\mathrm{b}}$ & 20.09 & 28.45 & $24.27^{\mathrm{a}}$ \\
\hline Glycine & 15.52 & 23.74 & $19.63^{a}$ & 14.64 & 18.00 & $16.32^{\mathrm{b}}$ \\
\hline Alanine & 32.63 & 40.05 & $36.34^{\mathrm{A}}$ & 22.65 & 25.63 & $24.14^{\mathrm{B}}$ \\
\hline Valine & 22.33 & 25.47 & $23.90^{\mathrm{a}}$ & 16.87 & 20.45 & $18.66^{b}$ \\
\hline Isoleucine & 18.67 & 21.07 & $19.87^{a}$ & 12.63 & 17.05 & $14.84^{b}$ \\
\hline Leucine & 29.91 & 32.15 & $31.03^{\mathrm{a}}$ & 21.79 & 27.15 & $24.47^{b}$ \\
\hline Tyrosine & 13.52 & 16.42 & $14.97^{\mathrm{a}}$ & 11.09 & 14.53 & $12.81^{b}$ \\
\hline Phenylalanine & 15.44 & 18.98 & 15.44 & 12.49 & 19.05 & 15.77 \\
\hline Histidine & 8.93 & 10.23 & 9.58 & 8.01 & 10.29 & 9.15 \\
\hline Lysine & 27.27 & 38.41 & $32.84^{\mathrm{A}}$ & 23.62 & 26.84 & $25.23^{B}$ \\
\hline Arginine & 12.31 & 23.89 & $18.10^{\mathrm{b}}$ & 19.05 & 23.29 & $21.17^{\mathrm{a}}$ \\
\hline Cystine & 2.55 & 6.21 & 4.38 & 4.38 & 5.08 & 4.73 \\
\hline Methionine & 4.73 & 9.69 & 7.21 & 5.99 & 7.71 & 6.85 \\
\hline Tryptophan & 5.99 & 7.04 & $6.51^{\mathrm{a}}$ & 4.03 & 5.67 & $4.85^{b}$ \\
\hline \multicolumn{7}{|c|}{ Minerals } \\
\hline Sodium & 12.81 & 19.38 & $16.11^{\mathrm{A}}$ & 7.87 & 8.93 & $8.40^{\mathrm{B}}$ \\
\hline Potassium & 19.10 & 25.14 & $22.12^{\mathrm{a}}$ & 16.41 & 18.27 & $17.34^{b}$ \\
\hline Sulphur & 3.53 & 6.21 & $4.87^{\mathrm{a}}$ & 3.33 & 4.07 & $3.70^{b}$ \\
\hline Calcium & 3.04 & 5.48 & $4.26^{\mathrm{A}}$ & 1.99 & 2.47 & $2.24^{\mathrm{B}}$ \\
\hline Phosphorus & 3.40 & 5.28 & $4.34^{\mathrm{B}}$ & 8.00 & 12.04 & $10.02^{\mathrm{A}}$ \\
\hline Magnesium & 1.82 & 2.04 & $1.93^{\mathrm{a}}$ & 1.30 & 1.66 & $1.48^{b}$ \\
\hline Manganese $\left(\mathrm{mg} \mathrm{kg}^{-1}\right)$ & 12.03 & 18.21 & $15.12^{\mathrm{A}}$ & 3.35 & 4.33 & $3.84^{\mathrm{B}}$ \\
\hline Zinc $\left(\mathrm{mg} \mathrm{kg}^{-1}\right)$ & 57.97 & 82.57 & $70.47^{\mathrm{a}}$ & 55 & 66.86 & $60.93^{b}$ \\
\hline Iron $\left(\mathrm{mg} \mathrm{kg}^{-1}\right)$ & 76.88 & 143.00 & 109.94 & 98.9 & 103.24 & 101.07 \\
\hline \multicolumn{7}{|c|}{ Vitamins } \\
\hline Vitamin E & 6.04 & 7.52 & $6.78^{\mathrm{B}}$ & 37.9 & 52.1 & $45.00^{\mathrm{A}}$ \\
\hline Vitamin $B_{1}$ & 80.76 & 115.24 & $98.00^{\mathrm{B}}$ & 100.8 & 136.8 & $118.8^{\mathrm{A}}$ \\
\hline Vitamin $B_{2}$ & 11.01 & 21.47 & $16.24^{\mathrm{A}}$ & 5.83 & 6.37 & $6.10^{\mathrm{B}}$ \\
\hline Vitamin $\mathrm{B}_{6}$ & 25.43 & 31.41 & 28.42 & 19.3 & 33.7 & 26.50 \\
\hline Vitamin $B_{12}\left(\mu \mathrm{g} \mathrm{kg}^{-1}\right)$ & 52.80 & 60.00 & $56.40^{\mathrm{A}}$ & 3.52 & 5.44 & $4.48^{\mathrm{B}}$ \\
\hline
\end{tabular}

$\mathrm{a}, \mathrm{b}$ average values with different letters differ significantly at $p \leq 0.05$; $\mathrm{A}, \mathrm{B}$ average values with different letters differ significantly at $p \leq 0.01$.

Czech et al. [24] also evaluated the impact of a Yarrowia lipolytica-enriched diet on piglets. In particular, the A-101 yeast strain was incorporated into 46-day-old piglets' rations at doses of 3\% and of $6 \%$ in place of equal amounts of soybean meal. Following a 39-day-long experimental trial, it emerged that the piglets which received 3\% Yarrowia lipolytica yeast in their diets were heavier on the $39^{\text {th }}$ day of the study compared to the control group and to the group that received the yeast at a rate of 6\%. Moreover, the piglets fed Yarrowia lipolytica yeast in the amount of $3 \%$ had higher growth rates and better feed efficiency than the control and the group receiving feed containing $6 \%$ Yarrowia lipolytica. Finally, throughout the whole experimental period, the piglets fed the mixture with $3 \%$ of Yarrowia lipolytica presented the lowest frequency of diarrhea. In contrast, in the group of piglets fed the highest percentage of Yarrowia lipolytica yeast, the observed diarrhea was more frequent and lasted longer. The reduced performance and the higher frequency of diarrhea noted in the piglets fed with 
$6 \%$ Yarrowia lipolytica yeast could be attributed to an adaptation of their organism to a higher amount of a supplement that not only contains essential nutrients but is also rich in many bioactive substances. Furthermore, this type of reaction could result from an excess dose of the yeast that could stimulate uncontrolled fermentation procedures in young piglets [24].

Recently, Czech et al. [72] compared the dietary effect of Yarrowia lipolytica and Saccharomyces cerevisiae yeasts on some hematological parameters and the gut microorganisms in growing piglets with or without the simultaneous use of probiotic additives. The 56-day-long feeding trial was carried out on 360, 28-day-old, weaned piglets, divided into six dietary groups. Piglets from groups C (control) and $\mathrm{P}$ were fed typical feed mixtures without yeast supplements, while in group $\mathrm{P}$ a probiotic (a mixture of Bacillus licheniformis and Bacillus subtilis) was also included to the ration at a dose of $2 \times 10^{9}$ $\mathrm{CFU} / \mathrm{kg}$ of feed. Piglets in group Y were fed typical feed mixtures with dried Yarrowia lipolytica yeast, and group YP dried Yarrowia lipolytica and probiotics. Animals from groups S and SP were fed with typical feed mixtures with dried yeast of the species S. cerevisiae, while the piglets in the SP group also received a probiotic. The chosen dose of the yeasts $(3 \%)$ was based on the outcomes of a previous study [24].

According to the findings of the trial, Yarrowia lipolytica yeast may be used interchangeably in weaned piglets' diets instead of S. cerevisiae. It was also revealed that Yarrowia lipolytica does not adversely affect the health of piglets, as the number of white cells remained within the reference range. Moreover, Yarrowia lipolytica appears to activate the immune system as manifested by the increased number of lymphocytes and IgG serum levels but also promotes erythropoiesis, as indicated by elevated hematocrit, hemoglobin content and erythrocyte count in the blood of piglets fed Yarrowia lipolytica yeast. The nutritional impact of Yarrowia lipolytica on the immune system and blood parameters of the piglets confirms the results of similar studies carried out in turkeys [41,70]. The supplementation of only yeast (Yarrowia lipolytica or S. cerevisiae) or probiotic alone to the piglets' ration reduced the total count of coliform bacteria in the intestinal contents as compared to the control. However, it was found that the combined application of Yarrowia lipolytica or S. cerevisiae yeast with a probiotic had a more favorable impact on the gut microflora than the use of yeast alone. It is worth mentioning, that supplementing piglets' diet with Yarrowia lipolytica together with a probiotic reduced the proliferation of coliform bacteria and Escherichia coli in the enteric contents; whereas supplementation with the mixture containing S. cerevisiae together with a probiotic did not. According to Czech et al. [72] the positive effect of Yarrowia lipolytica on hematological parameters and the microorganisms colonizing the intestinal truck of the piglets was found to be more beneficial than the impact of $S$. cerevisiae yeast. Consequently, the above-mentioned researchers concluded that Yarrowia lipolytica, when combined with a probiotic (a mixture of Bacillus licheniformis and Bacillus subtilis), is considerably appropriate for feeding piglets.

In another comparative study, Czech et al. [71] investigated the impact of dietary enrichment with Yarrowia lipolytica and S. cerevisiae yeasts with or without the simultaneous use of a probiotic on the performance, basic nutrients digestibility and some biochemical parameters in piglets. The experimental design of this study was the same as the previous work [72]. Throughout the experimental period, higher weight gain was recorded in the piglets that received Yarrowia lipolytica with their feed than the control and the group of piglets that received the S. cerevisiae yeast. This result could be attributed to a more favorable amino acid profile (especially lysine), and the minerals in Yarrowia lipolytica yeast, as well as to the better digestibility of nutrient components in animals of this group. The more willing consumption from pigs of the diet containing Yarrowia lipolytica as compared to the mixture containing the S. cerevisiae, could also explain this finding, since brewer's yeast has a bitter taste [24]. However, the apparent fecal digestibility of nutrient coefficients of crude protein, crude fat, crude fiber and nitrogen-free extract were not significantly different between experimental groups. Moreover, the performance of piglets fed the dietary mixture containing yeast (Yarrowia lipolytica or S. cerevisiae) and a probiotic was not significantly improved. On the other hand, the frequency of diarrhea recorded when both yeast and a probiotic were added in pigs' diets was lower. Additionally, the biochemical 
parameters analyzed in the piglets' blood, as well as the levels of minerals, remained within the reference range in all the treatment groups. It seems, however, that the incorporation of Yarrowia lipolytica at the rate of 3\% in growing pigs' diets modulates their lipid metabolism, as demonstrated by the reduced levels of total cholesterol, LDL-cholesterol fraction and triglycerides and the elevation of HDL-cholesterol in animals' blood serum. Several studies show that this kind of reaction by the organism may be related to the existence of $\beta$-glucans in the yeast cell wall which may regulate lipid metabolism [81]. It has been documented that $\beta$-glucans are capable of binding bile acids [82]. This effect of Yarrowia lipolytica on lipid metabolism is consistent with similar findings in dietary studies carried out in turkeys [41].

\subsection{Effects of Yarrowia Lipolytica as Feed for Fishes}

Atlantic salmon fillets are considered a very good source of very long chain (VLc) n-3 fatty acids that promote health. Atlantic salmon can convert 18:3 n-3 from vegetable oils to eicosapentaenoic acid (EPA) and docosahexaenoic acid (DHA), but not very effectively [83]. Since Atlantic salmon essential fatty acids needs are not exclusively covered by vegetable oils, it is necessary to add EPA and DHA to fish diet for ensuring their optimal growth and health [84-86]. Today, marine fish oils are the main source of n-3 highly unsaturated fatty acids (HUFAs) for salmon diets. Aquaculture absorbs about $85 \%$ of world fish oil production, and about half of aquaculture share goes to salmon and trout production $[87,88]$. The possibilities for increasing world catches of marine fish are restricted thus, in order to preserve development in salmon farming without compromising the beneficial health impacts of the salmon fillets, n-3 HUFAs of different origins are required.

Biomass of Yarrowia lipolytica yeast has been utilized as an alternate source of EPA in salmon aquaculture [74,75]. In the study of Hatlen et al. [75] the dried, heat killed biomass of the genetically modified 4305 strain of Yarrowia lipolytica yeast was served as a source of EPA in fish diet. This strain could produce almost $20 \%$ total lipid and $6 \%$ EPA on a dry weight basis. The biomass of Yarrowia lipolytica was incorporated into fish diets at three different levels (10\%, 20\% and 30\%), instead of fish meal, rapeseed oil and wheat meal. During the experimental period (95 days) the effects of Yarrowia lipolytica yeast on Atlantic salmons' productive traits as well as on their fillets' composition were evaluated. The research revealed that Yarrowia lipolytica biomass can substitute $20-30 \%$ of highly qualified raw materials in fish feed, without negatively affecting their productivity. In particular, the body weight of the fish fed with Yarrowia lipolytica was increased from $180 \mathrm{to} 400 \mathrm{~g}$. This increase in fish weight was comparable to that observed in groups fed control diets with either rapeseed oil or a mixture of rapeseed and fish oil. Incorporation levels of up to $20 \%$ yeast biomass in fish diets led to similar growth, feed conversion ratio (FCR), protein and energy retention recorded in groups fed control diets for fish up to approximately $400 \mathrm{~g}$. However, when incorporation percentage in salmons' feed was increased the FCR reached $30 \%$.

Hatlen et al. [75] also found that the apparent digestibility coefficient for energy, proteins and lipids (including n-3 fatty acids) decreased as the amount of Yarrowia lipolytica biomass added in the fish diet increased. The cells of Yarrowia lipolytica used in the study were mechanically disrupted. However, the decreased apparent digestibility for protein and fat indicates the need for further investigation in order to find ways to optimize the extent of yeast cell disruption. Former studies have demonstrated that even if the cell wall is disrupted, cell components, such as non-starch polysaccharides, may interact with digestion procedures leading in decreased nutrient digestibility [89]. The reduction in energy digestibility in diets supplemented with yeast biomass was to some extent the result of reduced protein and fat digestibility, even though the yeast itself has a considerable amount of indigestible carbohydrates that partially replaced wheat starch in the diets used in their study, thus contributing in decreased energy digestibility [75].

Regarding the composition of salmon fillet in fatty acids, the trial of Hatlen et al. [75] revealed that the ratio of EPA/DHA in the fillets of fish fed the yeast supplemented diets was higher compared to that recorded at the salmon fillets of the fish oil control group. On the other hand, the lower whole-body 
retention of EPA, and the highest retention of DPA (docosapentaenoic acid) and DHA, in comparison to the average fatty acid retention, indicates that the EPA provided by the yeast was converted to a certain degree into DPA and DHA in fish body. An important factor to be considered in the utilization of yeast Yarrowia lipolytica is the bioavailability of fat and EPA, which are produced intracellularly and are therefore protected from degradation enzymes in the fish intestines unless the cell wall of the yeast is entirely disrupted. Based on the outcomes on the apparent digestibility coefficient as well as on the apparent nutrient retention data, it was concluded that the yeast cell was not completely bioavailable [75]. Therefore, for commercial use, the issue of total cell disruption should be seriously considered and cost-effectively resolved to maximize benefit of the yeast biomass.

Berge et al. [74] used a strain of Yarrowia lipolytica yeast that was genetically modified to generate high levels of EPA as dietary component of Atlantic salmon. The purpose of the study was to investigate the effect of yeast cell washing and the disruption on growth, bioavailability and the fillet fatty acid composition of Atlantic salmon growing from 0.5 to $1 \mathrm{~kg}$. During the 112-day feeding experiment, four dietary treatments containing $200 \mathrm{~g} \mathrm{~kg}^{-1}$ yeast were formulated according to the yeast cell wall process (washing, cell disruption) as follows: (Unwashed/Not disrupted, Unwashed/Disrupted, Washed/Undisrupted, Washed/Disrupted) and were compared to a fishmeal-based control diet. Final body weights and final growth rates did not differ between the experimental treatments. Apparent lipid digestibility was strongly influenced by disruption of yeast biomass. Disruption of yeast cell wall increased the apparent digestibility of EPA from 32\% to $76 \%$ in Washed biomass, and from $26 \%$ to $76 \%$ in Unwashed biomass. The total amount of n-3 fatty acids deposited in the entire body of salmon fed the control diet was comparable to that recorded in fish fed diets supplemented with Disrupted yeast biomass. In contrast, fillet composition in n-3 fatty acids of fish fed Undisrupted biomass was significantly lower. It was also revealed that removing the leftover medium components by washing had no apparent impact on the utilization of EPA. According to Berge et al. [74], the conversion of EPA to DHA in fish bodies was evidenced by the deposition ratio $\mathrm{Rd}<1$ for EPA and $\mathrm{Rd}>1$ for DHA.

In an in vitro study, Alamillo et al. [76] examined the possible use of Yarrowia lipolytica strain N-6 isolated from a hypersaline natural environment as immunostimulant of the non-specific immune reaction of head-kidney and spleen Pacific red snapper (Lutjanus peru) leukocytes after challenge with Vibrio parahaemolyticus. It was documented that the presence of Yarrowia lipolytica yeast significantly decreased the $V$. parahaemolyticus load in spleen leukocytes. In vitro trials using head-kidney and spleen leukocytes revealed that the reaction to the $V$. parahaemolyticus infection showed that leukocyte pre-incubated with the Yarrowia lipolytica N-6 strain resulted in a significant increase in non-specific reactions of the immune system, such as respiratory burst, phagocytic activity, nitric oxide production (NO) and myeloperoxidase activity (MPO) and simultaneously suspended the leukocyte apoptosis caused by $V$. parahaemolyticus. Similarly, superoxide dismutase (SOD) activity in both the head-kidney and spleen leukocytes, and catalase (CAT) activity in the spleen leukocytes were increased by the yeast. Furthermore, the incubation of leukocytes with yeast Yarrowia lipolytica N-6 also regulated the transcription of genes associated with immunity (IL-1 $\beta$ ) or oxidative stress (MnSOD, icCu/ZnSOD or CAT) in leukocytes. According to Alamillo et al. [76], these results reinforce the view that the isolated strain of yeast Yarrowia lipolytica N-6 can activate the non-specific immune parameters and the antioxidant immune mechanism in head-kidney and spleen Pacific red snapper leukocytes and could therefore be applied as possible immunostimulant.

In vivo oral feeding tests were also conducted in the marine fish Cynoglossus semilaevis in order to investigate the use of the SCP of Yarrowia lipolytica biomass grown on crude glycerol, as feed additive [53]. In those trials, diets containing various dosages of SCP of Yarrowia lipolytica ranging from $0.5-3 \%$ were fed to fishes of $46-56 \mathrm{~g}$ body weight for 32 days and their growth was recorded. The findings of these experiments indicate that the supplementation of fish diet with the proper amount of SCP improves fish growth, as well as the specific growth rate (SGR). It was shown that incorporation rates of SCP higher than $2 \%$ have no further positive impact. However, inclusion of SCP in fish diet at doses less than $2 \%$ is considered inadequate, while doses higher than $2 \%$ sufficiently promote growth 
performance. The later beneficial impact is linked to a variety of functional ingredients (crude proteins, nuclei acids, lipids, carbohydrates, vitamins, mineral elements etc.) found in SCP. Based on those results Yan et al. [53] concluded that the SCP of Yarrowia lipolytica biomass is an excellent additive for fish feeding.

\section{Conclusions}

Yarrowia lipolytica is an oleaginous, non-pathogenic yeast, which shows significant potential to be employed as SCP in animal feed. Apart from its high protein content, which may reach up to $60 \% w / w$ of its dry weight, it can store intracellular biolipids that further increase its nutritional value. Given that the main production cost of SCP is the substrate cost, the use of low- or no-cost AWCBs for the growth of Yarrowia lipolytica can improve both the economic as well as the environmental sustainability of the production process. Only a handful of studies have assessed the environmental sustainability of yeast-based SCP production and have denoted the significant reduction in the environmental footprint of animal feeds, supplemented with SCP of yeast origin, compared to the base-case scenario of soybean meal. Therefore, locally produced SCP, grown on locally available AWCBs, arises as a more environmentally sustainable process, than the import of soybean meal for animal protein-deficient areas/countries. Although the complete substitution of plant-derived proteins for animal feeds does not seem to be a realistic scenario (at least in the near future) for economic and technological issues, the partial substitution of plant-derived proteins from Yarrowia lipolytica (as well as other SCPs) grown on AWCBs would be an excellent paradigm in the context of circular economy.

The addition of Yarrowia lipolytica in animal feed ratios may be further developed given that the available scientific data denote that Yarrowia lipolytica biomass has a high nutritional value, comparable to and to some points superior to that of Saccharomyces cerevisiae (e.g., brewer's yeast). It provides animals with precious minerals, vitamins, high quality proteins, especially EAA, and is a source of polyunsaturated fatty acids. Under the current legal regime in EU, Yarrowia lipolytica strain grown in raw glycerol (the main by-product stream of biodiesel industry), is considered safe for use in animal feed. Moreover, to date, studies have shown that the inclusion of Yarrowia lipolytica in the diet of productive animals has a positive effect on their health and performance. In summary, it seems to: (a) increase body weight gain, (b) improve the feed conversion ratio, (c) positively influence intestinal microflora, (d) stimulate antioxidant mechanisms and the immune system, e) promote erythropoietic processes and (f) increase the metabolic status of animals. Based on these properties, Yarrowia lipolytica biomass is considered an animal feed supplement of high nutritional value substituting part of the currently used vegetable protein.

Concerning technical aspects, the growth of Yarrowia lipolytica on various hydrophobic and hydrophilic AWCB substrates has been well-documented in numerous studies. Yarrowia lipolytica is a versatile microorganism that can naturally metabolize many different substrates, whereas it can be genetically engineered to expand the range of usable carbon sources. Moreover, it can grow under acidic $\mathrm{pH}$, thus greatly reducing the risk of contamination under ambient temperature conditions, and it can tolerate high salt concentrations and the existence of anti-microbial (e.g., polyphenols) substances in the substrate medium. Unfortunately, most of the reports are lab-scale trials in small bioreactors, operated under batch and fed-batch conditions, with only one reported case of commercial production of Yarrowia lipolytica SCP grown on raw glycerol. Therefore, there is a need to scale-up laboratory results to semi-industrial and industrial scales through the technological advancement of laboratory practices and protocols. This scale-up process would also provide further data that would facilitate a detailed assessment of the economic, environmental and social sustainability of the commercialization of Yarrowia lipolytica production for animal feed properties.

The commercialization of the use of Yarrowia lipolytica in animal feeds can be also facilitated through further research on its effect on animal's health, productivity, and welfare. While much attention has been placed on the safety of Yarrowia lipolytica additions in animal feed, more research can be done on feeding Yarrowia lipolytica to different species of productive animals (e.g., broilers), and 
to different age groups, with emphasis on the optimum incorporation level of the yeast in animals' diets to ameliorate animal productivity without compromising their health. Moreover, little has been done on exploring the best ways of supplementing this yeast into the ratio of productive animals so that it can fully meet their needs, and on finding economical ways to optimize the yeast cell disruption to increase the bioavailability of fat and EAA which are produced intracellularly. The duration of the experimental trials is another issue that should be closely looked upon when aiming to assess the long-term dietary effect on animals' performance and health status. Finally, it would be of great interest to shed light on the possible mechanisms by which Yarrowia lipolytica influences the gut microflora, stimulates antioxidants and the immune system, promotes erythropoietic processes and increases animals' metabolic status when added to their diet. The experience and knowledge gained through such studies would increase the general confidence in the positive effect of Yarrowia lipolytica on animal health, productivity, and welfare, and would increase its acceptance by animal farmers.

Author Contributions: Conceptualization, E.N.S., S.I.P. and A.D. writing—original draft preparation, S.I.P. and A.D. writing-review and editing, A.Z. and E.N.S. All authors have read and agreed to the published version of the manuscript.

Funding: This research has been co-financed by the European Regional Development Fund of the European Union and Greek national funds through the Operational Program Competitiveness, Entrepreneurship and Innovation, under the call RESEARCH-CREATE-INNOVATE (project code: T1EDK-02871).

Conflicts of Interest: The authors declare no conflict of interest.

\section{References}

1. WHO. 3.4 Availability and changes in consumption of animal products. Available online: https://www.who. int/nutrition/topics/3_foodconsumption/en/index4.html (accessed on 11 September 2019).

2. United Nations, Department of Economic and Social Affairs, Population Division. World Population Prospects 2019: Highlights (ST/ESA/SER.A/423). Available online: https://population.un.org/wpp/ (accessed on 15 September 2019).

3. Kim, S.W.; Less, J.F.; Wang, L.; Yan, T.; Kiron, V.; Kaushik, S.J.; Lei, X.G. Meeting Global Feed Protein Demand: Challenge, Opportunity, and Strategy. Annu. Rev. Anim. Biosci. 2019, 7, 221-243. [CrossRef]

4. Office of Global Analysis, F.A.S. Oilseeds: World Markets and Trade; United States Department of Agriculture: Washington, DC, USA, 2019.

5. Dalgaard, R.; Schmidt, J.; Halberg, N.; Christensen, P.; Thrane, M.; Pengue, W.A. LCA of soybean meal. Int. J. Life Cycle Assess. 2007, 13, 240. [CrossRef]

6. Lehuger, S.; Gabrielle, B.; Gagnaire, N. Environmental impact of the substitution of imported soybean meal with locally-produced rapeseed meal in dairy cow feed. J. Clean. Prod. 2009, 17, 616-624. [CrossRef]

7. Tallentire, C.W.; Mackenzie, S.G.; Kyriazakis, I. Can novel ingredients replace soybeans and reduce the environmental burdens of European livestock systems in the future? J. Clean. Prod. 2018, 187, 338-347. [CrossRef]

8. Powell, K.A.; Rodgers, B.L.F. Single-cell protein. In Methylotrophs: Microbiology, Biochemistry and Genetics; CRC Press: Boca Raton, FL, USA, 2018; pp. 119-144. [CrossRef]

9. Ritala, A.; Häkkinen, S.T.; Toivari, M.; Wiebe, M.G. Single Cell Protein-State-of-the-Art, Industrial Landscape and Patents 2001-2016. Front. Microbiol. 2017, 8. [CrossRef]

10. Braude, R. Dried yeast as fodder for livestock. J. Inst. Brew. 1942, 48, 206-212. [CrossRef]

11. Groenewald, M.; Boekhout, T.; Neuvéglise, C.; Gaillardin, C.; Van Dijck, P.W.M.; Wyss, M. Yarrowia lipolytica: Safety assessment of an oleaginous yeast with a great industrial potential. Crit. Rev. Microbiol. 2014, 40, 187-206. [CrossRef]

12. Nasseri, A.T.; Rasoul-Amini, S.; Morowvat, M.H.; Younes, G. Single Cell Protein: Production and Process. Am. J. Food Technol. 2011, 6. [CrossRef]

13. Carsanba, E.; Papanikolaou, S.; Erten, H. Production of oils and fats by oleaginous microorganisms with an emphasis given to the potential of the nonconventional yeast Yarrowia lipolytica. Crit. Rev. Biotechnol. 2018, 38, 1230-1243. [CrossRef] 
14. Kieliszek, M.; Kot, A.M.; Bzducha-Wróbel, A.; BŁażejak, S.; Gientka, I.; Kurcz, A. Biotechnological use of Candida yeasts in the food industry: A review. Fungal Biol. Rev. 2017, 31, 185-198. [CrossRef]

15. Kurcz, A.; Błażejak, S.; Kot, A.M.; Bzducha-Wróbel, A.; Kieliszek, M. Application of Industrial Wastes for the Production of Microbial Single-Cell Protein by Fodder Yeast Candida utilis. Waste Biomass Valorization 2018, 9, 57-64. [CrossRef]

16. Beopoulos, A.; Cescut, J.; Haddouche, R.; Uribelarrea, J.-L.; Molina-Jouve, C.; Nicaud, J.-M. Yarrowia lipolytica as a model for bio-oil production. Prog. Lipid Res. 2009, 48, 375-387. [CrossRef] [PubMed]

17. Madzak, C. Engineering Yarrowia lipolytica for Use in Biotechnological Applications: A Review of Major Achievements and Recent Innovations. Mol. Biotechnol. 2018, 60, 621-635. [CrossRef] [PubMed]

18. Liu, H.-H.; Ji, X.-J.; Huang, H. Biotechnological applications of Yarrowia lipolytica: Past, present and future. Biotechnol. Adv. 2015, 33, 1522-1546. [CrossRef]

19. Darvishi, F.; Fathi, Z.; Ariana, M.; Moradi, H. Yarrowia lipolytica as a workhorse for biofuel production. Biochem. Eng. J. 2017, 127, 87-96. [CrossRef]

20. Darvishi, F.; Ariana, M.; Marella, E.R.; Borodina, I. Advances in synthetic biology of oleaginous yeast Yarrowia lipolytica for producing non-native chemicals. Appl. Microbiol. Biotechnol. 2018, 102, 5925-5938. [CrossRef]

21. Turck, D.; Castenmiller, J.; de Henauw, S.; Hirsch-Ernst, K.; Kearney, J.; Maciuk, A.; Mangelsdorf, I.; McArdle, H.J.; Naska, A.; Pelaez, C.; et al. Safety of Yarrowia lipolytica yeast biomass as a novel food pursuant to regulation (EU) 2015/2283. Efsa J. 2019, 17. [CrossRef]

22. Spagnuolo, M.; Hussain, M.S.; Gambill, L.; Blenner, M. Alternative substrate metabolism in Yarrowia lipolytica. Front. Microbiol. 2018, 9. [CrossRef]

23. Morgunov, I.G.; Kamzolova, S.V.; Lunina, J.N. Citric acid production by Yarrowia lipolytica Yeast on different renewable raw materials. Fermentation 2018, 4, 36. [CrossRef]

24. Czech, A.; Smolczyk, A.; Ognik, K.; Kiesz, M. Nutritional Value of Yarrowia Lipolytica Yeast and its Effect on Growth Performance Indicators n Piglets. Ann. Anim. Sci. 2016, 16, 1091-1100. [CrossRef]

25. Michalik, B.; Biel, W.; Lubowicki, R.; Jacyno, E. Chemical composition and biological value of proteins of the yeast Yarrowia lipolytica growing on industrial glycerol. Can. J. Anim. Sci. 2014, 94, 99-104. [CrossRef]

26. Ogrydziak, D.M.; Nicaud, J.-M. Characterization of Yarrowia lipolytica XPR2 multi-copy strains over-producing alkaline extracellular protease-A system for rapidly increasing secretory pathway cargo loads. Fems Yeast Res. 2012, 12, 938-948. [CrossRef] [PubMed]

27. Lindquist, M.R.; López-Núñez, J.C.; Jones, M.A.; Cox, E.J.; Pinkelman, R.J.; Bang, S.S.; Moser, B.R.; Jackson, M.A.; Iten, L.B.; Kurtzman, C.P.; et al. Irradiation of Yarrowia lipolytica NRRL YB-567 creating novel strains with enhanced ammonia and oil production on protein and carbohydrate substrates. Appl. Microbiol. Biotechnol. 2015, 99, 9723-9743. [CrossRef] [PubMed]

28. Soong, Y.H.V.; Liu, N.; Yoon, S.; Lawton, C.; Xie, D. Cellular and metabolic engineering of oleaginous yeast Yarrowia lipolytica for bioconversion of hydrophobic substrates into high-value products. Eng. Life Sci. 2019, 19, 423-443. [CrossRef]

29. Ma, Y.R.; Wang, K.F.; Wang, W.J.; Ding, Y.; Shi, T.Q.; Huang, H.; Ji, X.J. Advances in the metabolic engineering of Yarrowia lipolytica for the production of terpenoids. Bioresour. Technol. 2019, 281, 449-456. [CrossRef]

30. Larroude, M.; Rossignol, T.; Nicaud, J.M.; Ledesma-Amaro, R. Synthetic biology tools for engineering Yarrowia lipolytica. Biotechnol. Adv. 2018, 36, 2150-2164. [CrossRef]

31. Shi, T.Q.; Huang, H.; Kerkhoven, E.J.; Ji, X.J. Advancing metabolic engineering of Yarrowia lipolytica using the CRISPR/Cas system. Appl. Microbiol. Biotechnol. 2018, 102, 9541-9548. [CrossRef]

32. Abdel-Mawgoud, A.M.; Markham, K.A.; Palmer, C.M.; Liu, N.; Stephanopoulos, G.; Alper, H.S. Metabolic engineering in the host Yarrowia lipolytica. Metab. Eng. 2018, 50, 192-208. [CrossRef]

33. Gálvez-López, D.; Chávez-Meléndez, B.; Vázquez-Ovando, A.; Rosas-Quijano, R. The metabolism and genetic regulation of lipids in the oleaginous yeast Yarrowia lipolytica. Braz. J. Microbiol. 2019, 50, $23-31$. [CrossRef]

34. Lazar, Z.; Liu, N.; Stephanopoulos, G. Holistic Approaches in Lipid Production by Yarrowia lipolytica. Trends Biotechnol. 2018, 36, 1157-1170. [CrossRef]

35. Zeng, S.Y.; Liu, H.H.; Shi, T.Q.; Song, P.; Ren, L.J.; Huang, H.; Ji, X.J. Recent Advances in Metabolic Engineering of Yarrowia lipolytica for Lipid Overproduction. Eur. J. Lipid Sci. Technol. 2018, 120. [CrossRef]

36. Xie, D. Integrating cellular and bioprocess engineering in the non-conventional yeast Yarrowia lipolytica for biodiesel production: A review. Front. Bioeng. Biotechnol. 2017, 5. [CrossRef] [PubMed] 
37. Zhu, Q.; Jackson, E.N. Metabolic engineering of Yarrowia lipolytica for industrial applications. Curr. Opin. Biotechnol. 2015, 36, 65-72. [CrossRef] [PubMed]

38. Hu, W.; Li, W.J.; Yang, H.Q.; Chen, J.H. Current strategies and future prospects for enhancing microbial production of citric acid. Appl. Microbiol. Biotechnol. 2019, 103, 201-209. [CrossRef]

39. Couture, J.L.; Geyer, R.; Hansen, J.O.; Kuczenski, B.; Øverland, M.; Palazzo, J.; Sahlmann, C.; Lenihan, H. Environmental Benefits of Novel Nonhuman Food Inputs to Salmon Feeds. Environ. Sci. Technol. 2019, 53, 1967-1975. [CrossRef]

40. De Visser, C.L.M.; Schreuder, R.; Stoddard, F. The EU's dependency on soya bean import for the animal feed industry and potential for EU produced alternatives. OCL 2014, 21, D407. [CrossRef]

41. Czech, A.; Merska, M.; Ognik, K. Blood Immunological and Biochemical Indicators in Turkey Hens Fed Diets With a Different Content of the Yeast Yarrowia Lipolytica. Ann. Anim. Sci. 2014, 14, 935-946. [CrossRef]

42. Scioli, C.; Vollaro, L. The use of Yarrowia lipolytica to reduce pollution in olive mill wastewaters. Water Res. 1997, 31, 2520-2524. [CrossRef]

43. Ledesma-Amaro, R.; Nicaud, J.M. Metabolic Engineering for Expanding the Substrate Range of Yarrowia lipolytica. Trends Biotechnol. 2016, 34, 798-809. [CrossRef]

44. Ledesma-Amaro, R.; Nicaud, J.M. Yarrowia lipolytica as a biotechnological chassis to produce usual and unusual fatty acids. Prog. Lipid Res. 2016, 61, 40-50. [CrossRef]

45. Zinjarde, S.; Apte, M.; Mohite, P.; Kumar, A.R. Yarrowia lipolytica and pollutants: Interactions and applications. Biotechnol. Adv. 2014, 32, 920-933. [CrossRef] [PubMed]

46. Bankar, A.V.; Kumar, A.R.; Zinjarde, S.S. Environmental and industrial applications of Yarrowia lipolytica. Appl. Microbiol. Biotechnol. 2009, 84, 847. [CrossRef] [PubMed]

47. Sarris, D.; Rapti, A.; Papafotis, N.; Koutinas, A.A.; Papanikolaou, S. Production of added-value chemical compounds through bioconversions of olive-mill wastewaters blended with Crude glycerol by a Yarrowia lipolytica strain. Molecules 2019, 24, 222. [CrossRef] [PubMed]

48. Louhasakul, Y.; Cheirsilp, B.; Maneerat, S.; Prasertsan, P. Potential use of flocculating oleaginous yeasts for bioconversion of industrial wastes into biodiesel feedstocks. Renew. Energy 2019, 136, 1311-1319. [CrossRef]

49. Lopes, M.; Miranda, S.M.; Alves, J.M.; Pereira, A.S.; Belo, I. Waste Cooking Oils as Feedstock for Lipase and Lipid-Rich Biomass Production. Eur. J. Lipid Sci. Technol. 2019, 121. [CrossRef]

50. Juszczyk, P.; Rymowicz, W.; Kita, A.; Rywińska, A. Biomass production by Yarrowia lipolytica yeast using waste derived from the production of ethyl esters of polyunsaturated fatty acids of flaxseed oil. Ind. Crop. Prod. 2019, 138. [CrossRef]

51. Dobrowolski, A.; Drzymała, K.; Rzechonek, D.A.; Mituła, P.; Mirończuk, A.M. Lipid production from waste materials in seawater-based medium by the yeast Yarrowia lipolytica. Front. Microbiol. 2019, 10. [CrossRef]

52. Darvishi, F.; Salmani, N.; Hosseini, B. Biovalorization of vegetable oil refinery wastewater into value-added compounds by Yarrowia lipolytica. J. Chem. Technol. Biotechnol. 2019, 94, 2961-2968. [CrossRef]

53. Yan, J.; Han, B.; Gui, X.; Wang, G.; Xu, L.; Yan, Y.; Madzak, C.; Pan, D.; Wang, Y.; Zha, G.; et al. Engineering Yarrowia lipolytica to Simultaneously Produce Lipase and Single Cell Protein from Agro-industrial Wastes for Feed. Sci. Rep. 2018, 8. [CrossRef]

54. Han, Z.; Park, A.; Su, W.W. Valorization of papaya fruit waste through low-cost fractionation and microbial conversion of both juice and seed lipids. Rsc Adv. 2018, 8, 27963-27972. [CrossRef]

55. Rzechonek, D.A.; Dobrowolski, A.; Rymowicz, W.; Mirończuk, A.M. Aseptic production of citric and isocitric acid from crude glycerol by genetically modified Yarrowia lipolytica. Bioresour. Technol. 2019, 271, 340-344. [CrossRef] [PubMed]

56. Krzysztof, C.; Ludwika, T.H.; Magdalena, R.; Wojciech, Ł.; Waldemar, R.; Anita, R. The bioconversion of waste products from rapeseed processing into keto acids by Yarrowia lipolytica. Ind. Crop. Prod. 2018, 119, 102-110. [CrossRef]

57. Sarris, D.; Stoforos, N.G.; Mallouchos, A.; Kookos, I.K.; Koutinas, A.A.; Aggelis, G.; Papanikolaou, S. Production of added-value metabolites by Yarrowia lipolytica growing in olive mill wastewater-based media under aseptic and non-aseptic conditions. Eng. Life Sci. 2017, 17, 695-709. [CrossRef]

58. Ong, K.L.; Li, C.; Li, X.; Zhang, Y.; Xu, J.; Lin, C.S.K. Co-fermentation of glucose and xylose from sugarcane bagasse into succinic acid by Yarrowia lipolytica. Biochem. Eng. J. 2019, 148, 108-115. [CrossRef]

59. Liu, L.; You, Y.; Deng, H.; Guo, Y.; Meng, Y. Promoting hydrolysis of apple pomace by pectinase and cellulase to produce microbial oils using engineered Yarrowia lipolytica. Biomass Bioenergy 2019, 126, 62-69. [CrossRef] 
60. Li, C.; Ong, K.L.; Yang, X.; Lin, C.S.K. Bio-refinery of waste streams for green and efficient succinic acid production by engineered Yarrowia lipolytica without $\mathrm{pH}$ control. Chem. Eng. J. 2019, 804-812. [CrossRef]

61. Johnravindar, D.; Karthikeyan, O.P.; Selvam, A.; Murugesan, K.; Wong, J.W.C. Lipid accumulation potential of oleaginous yeasts: A comparative evaluation using food waste leachate as a substrate. Bioresour. Technol. 2018, 248, 221-228. [CrossRef]

62. Pereira, A.d.S.; Fontes-Sant'Ana, G.C.; Amaral, P.F.F. Mango agro-industrial wastes for lipase production from Yarrowia lipolytica and the potential of the fermented solid as a biocatalyst. Food Bioprod. Process. 2019, 115, 68-77. [CrossRef]

63. Anupama; Ravindra, P. Value-added food: Single cell protein. Biotechnol. Adv. 2000, 18, 459-479. [CrossRef]

64. Heuzé, V.; Tran, G.; Kaushik, S. Soybean meal. Feedipedia, a programme by INRA, CIRAD, AFZ and FAO. 2019. Available online: https://www.feedipedia.org/node/674 (accessed on 4 October 2019).

65. Heuzé, V.; Tran, G.; Sauvant, D.; Lessire, M.; Lebas, F. Rapeseed meal. Feedipedia, a programme by INRA, CIRAD, AFZ and FAO. 2019. Available online: https://feedipedia.org/node/52. (accessed on 2 October 2019).

66. European Commission. Commission Regulation (EU) 2017/1017 of 15 June 2017 amending Regulation (EU) No 68/2013 on the Catalogue of feed materials (Text with EEA relevance). Off. J. Eur. Union L159/48- L159/119 2017. Available online: http://data.europa.eu/eli/reg/2017/1017/oj (accessed on 12 November 2019).

67. Rywińska, A.; Juszczyk, P.; Wojtatowicz, M.; Robak, M.; Lazar, Z.; Tomaszewska, L.; Rymowicz, W. Glycerol as a promising substrate for Yarrowia lipolytica biotechnological applications. Biomass Bioenergy 2013, 48, 148-166. [CrossRef]

68. Michalik, B.; Jacyno, E.; Lubowicki, R.; Biel, W. Biological evaluation of the protein nutritional value in the diets of rats based on cereals and the yeast Yarrowia lipolytica growing on industrial glycerol. Acta Agric. Scand. Sect. A Anim. Sci. 2013, 63, 163-168. [CrossRef]

69. Merska, M.; Czech, A.; Ognik, K. The effect of yeast Yarrowia lipolytica on the antioxidant indices and macro-and microelements in blood plasma of turkey hens. Pol. J. Vet. Sci. 2015, 18, 709-714. [CrossRef] [PubMed]

70. Merska-Kazanowska, M.; Czech, A.; Katarzyna, O. The effect of different doses of dried yeast Yarrowia lipolytica on production effects of turkey hens and hematological indicators of blood. Ann. Univ. Mariae Curie Skłodowska Sect. Ee Zootech. 2013, 31, 35-41.

71. Czech, A.; Smolczyk, A.; Grela, E.R.; Kiesz, M. Effect of dietary supplementation with Yarrowia lipolytica or Saccharomyces cerevisiae yeast and probiotic additives on growth performance, basic nutrients digestibility and biochemical blood profile in piglets. J. Anim. Physiol. Anim. Nutr. 2018, 102, 1720-1730. [CrossRef] [PubMed]

72. Czech, A.; Smolczyk, A.; Ognik, K.; Wlazło, Ł.; Nowakowicz-Dębek, B.; Kiesz, M. Effect of dietary supplementation with Yarrowia lipolytica or Saccharomyces cerevisiae yeast and probiotic additives on haematological parameters and the gut microbiota in piglets. Res. Vet. Sci. 2018, 119, 221-227. [CrossRef] [PubMed]

73. Stefańska, B.; Komisarek, J.; Stanisławski, D.; Gąsiorek, M.; Kasprowicz-Potocka, M.; Frankiewicz, A.; Nowak, W. The effect of Yarrowia lipolytica culture on growth performance, ruminal fermentation and blood parameters of dairy calves. Anim. Feed Sci. Technol. 2018, 243, 72-79. [CrossRef]

74. Berge, G.M.; Hatlen, B.; Odom, J.M.; Ruyter, B. Physical treatment of high EPA Yarrowia lipolytica biomass increases the availability of n-3 highly unsaturated fatty acids when fed to Atlantic salmon. Aquac. Nutr. 2013, 19, 110-121. [CrossRef]

75. Hatlen, B.; Berge, G.M.; Odom, J.M.; Mundheim, H.; Ruyter, B. Growth performance, feed utilisation and fatty acid deposition in Atlantic salmon, Salmo salar L., fed graded levels of high-lipid/high-EPA Yarrowia lipolytica biomass. Aquaculture 2012, 364-365, 39-47. [CrossRef]

76. Alamillo, E.; Reyes-Becerril, M.; Cuesta, A.; Angulo, C. Marine yeast Yarrowia lipolytica improves the immune responses in Pacific red snapper (Lutjanus peru) leukocytes. Fish Shellfish Immunol. 2017, 70, 48-56. [CrossRef]

77. Melo, L.Q.; Costa, S.F.; Lopes, F.; Guerreiro, M.C.; Armentano, L.E.; Pereira, M.N. Rumen morphometrics and the effect of digesta $\mathrm{pH}$ and volume on volatile fatty acid absorption. J. Anim. Sci. 2013, 91, 1775-1783. [CrossRef]

78. DeFrain, J.M.; Hippen, A.R.; Kalscheur, K.F.; Schingoethe, D.J. Feeding lactose increases ruminal butyrate and plasma beta-hydroxybutyrate in lactating dairy cows. J. Dairy Sci. 2004, 87, 2486-2494. [CrossRef] 
79. Rashid, M.A.; Pasha, T.; Jabbar, M.; Ahmad, I. Changes in blood metabolites of early weaned Nili-Ravi buffalo (Bubalus Bubalis) calves. J. Anim. Plant Sci. 2013, 23, 1067-1071.

80. Khan, M.A.; Lee, H.J.; Lee, W.S.; Kim, H.S.; Kim, S.B.; Ki, K.S.; Ha, J.K.; Lee, H.G.; Choi, Y.J. Pre- and postweaning performance of holstein female calves fed milk through step-down and conventional methods. J. Dairy Sci. 2007, 90, 876-885. [CrossRef]

81. Czech, A.; Mokrzycka, A.; Grela, E.R.; Pejsak, Z. Influence of mannanoligosaccharides additive to sows diets on blood parameters of sows and their piglets. Bull. Vet. Inst. Pulawy 2009, 53, 89-95.

82. Sadiq Butt, M.; Tahir-Nadeem, M.; Khan, M.K.; Shabir, R.; Butt, M.S. Oat: Unique among the cereals. Eur. J. Nutr. 2008, 47, 68-79. [CrossRef] [PubMed]

83. Bell, M.V.; Dick, J.R. Changes in capacity to synthesise 22:6n-3 during early development in rainbow trout (Oncorhynchus mykiss). Aquaculture 2004, 235, 393-409. [CrossRef]

84. Ruyter, B.; Røsjø, C.; Einen, O.; Thomassen, M.S. Essential fatty acids in Atlantic salmon: Effects of increasing dietary doses of n-6 and n-3 fatty acids on growth, survival and fatty acid composition of liver, blood and carcass. Aquac. Nutr. 2000, 6, 119-127. [CrossRef]

85. Ruyter, B.; Røsjø, C.; Einen, O.; Thomassen, M.S. Essential fatty acids in Atlantic Salmon: Time course of changes in fatty acid composition of liver, blood and carcass induced by a diet deficient in n-3 and n- 6 fatty acids. Aquac. Nutr. 2000, 6, 109-117. [CrossRef]

86. Ruyter, B.; Røsjø, C.; Måsøval, K.; Einen, O.; Thomassen, M.S. Influence of dietary n-3 fatty acids on the desaturation and elongation of [1-14C] 18:2 n-6 and [1-14C] 18:3 n-3 in Atlantic salmon hepatocytes. Fish Physiol. Biochem. 2000, 23, 151-158. [CrossRef]

87. Tacon, A.G.J.; Metian, M. Global overview on the use of fish meal and fish oil in industrially compounded aquafeeds: Trends and future prospects. Aquaculture 2008, 285, 146-158. [CrossRef]

88. FAO. The State of World Fisheries and Aquaculture, 2008; FAO Fisheries and Aquaculture Department, Food and Agriculture Organization of the United Nations: Rome, Italy, 2009; p. 176.

89. Glencross, B. The influence of soluble and insoluble lupin non-starch polysaccharides on the digestibility of diets fed to rainbow trout (Oncorhynchus mykiss). Aquaculture 2009, 294, 256-261. [CrossRef] 